\title{
Toxicity thresholds of three insecticides and two fungicides to larvae of the coral Acropora tenuis
}

\author{
Florita Flores ${ }^{\text {Corresp., } 1}$, Sarit Kaserzon ${ }^{2}$, Gabriele Elisei ${ }^{2}{ }^{2}$ Gerard Ricardo $^{1}{ }^{1}$, Andrew P Negri ${ }^{1}$ \\ ${ }^{1}$ Australian Institute of Marine Science, Townsville, Queensland, Australia \\ 2 Queensland Alliance for Environmental Health Sciences (QAEHS), The University of Queensland, Woolloongabba, Queensland, Australia \\ Corresponding Author: Florita Flores \\ Email address: f.flores@aims.gov.au
}

Tropical marine ecosystems, such as coral reefs, face several threats to their health and resilience, including poor water quality. Previous studies on the risks posed by pesticides have focused on five priority herbicides; however, as the number of pesticides applied in coastal agriculture increases, a suite of 'alternative' pesticides is being detected in tropical nearshore waters. To improve our understanding of the risks posed by alternative pesticides to tropical marine organisms, the effects of three insecticides (diazinon, fipronil, imidacloprid) and two fungicides (chlorothalonil, propiconazole) were tested on larval metamorphosis of the coral Acropora tenuis. A. tenuis larvae were affected by all five pesticides and the reference toxicant copper. The no effect concentration (NEC) and the $10 \%$ and $50 \%$ effect concentrations $\left(\mathrm{EC}_{10}\right.$ and $\mathrm{EC}_{50}$, respectively) for larval metamorphosis were estimated from concentration-response curves after $48 \mathrm{~h}$ exposure. The NEC, EC 10 and $\mathrm{EC}_{50}$ (in $\mu \mathrm{g} \mathrm{L}^{-1}$ ), respectively, of each pesticide were as follows: chlorothalonil $(2.4,2.8$, $6.0)$; fipronil $(12.3,13.9,29.1)$; diazinon $(38.0,40.8,54.7)$; imidacloprid $(263,273,347)$; and propiconazole $(269,330,1008)$. These toxicity thresholds are higher than reported concentrations in monitoring programs; however, these data will contribute to improving water quality guideline values, which inform the total risk assessments posed by complex contaminant mixtures to which these pesticides contribute. 


\section{Toxicity thresholds of three insecticides and two fungicides to 2 larvae of the coral Acropora tenuis}

4 Florita Flores ${ }^{1}$, Sarit Kaserzon ${ }^{2}$, Gabriele Elisei ${ }^{2}$, Gerard Ricardo ${ }^{1}$, Andrew P Negri ${ }^{1}$

$5{ }^{1}$ Australian Institute of Marine Science, Townsville, QLD 4810, Australia

$6{ }^{2}$ Queensland Alliance for Environmental Health Sciences (QAEHS), The University of

7 Queensland, Woolloongabba, QLD 4102, Australia

9 Corresponding Author:

10 Florita Flores ${ }^{1}$

11 PMB No. 3, Townsville, QLD 4810, Australia

12 Email address: f.flores@aims.gov.au 
13

14

\section{Abstract}

Tropical marine ecosystems, such as coral reefs, face several threats to their health and resilience, including poor water quality. Previous studies on the risks posed by pesticides have focused on five priority herbicides; however, as the number of pesticides applied in coastal agriculture increases, a suite of 'alternative' pesticides is being detected in tropical nearshore waters. To improve our understanding of the risks posed by alternative pesticides to tropical marine organisms, the effects of three insecticides (diazinon, fipronil, imidacloprid) and two fungicides (chlorothalonil, propiconazole) were tested on larval metamorphosis of the coral Acropora tenuis. A. tenuis larvae were affected by all five pesticides and the reference toxicant copper. The no effect concentration (NEC) and the $10 \%$ and $50 \%$ effect concentrations (EC 10 and $\mathrm{EC}_{50}$, respectively) for larval metamorphosis were estimated from concentration-response curves after $48 \mathrm{~h}$ exposure. The NEC, $\mathrm{EC}_{10}$ and $\mathrm{EC}_{50}$ (in $\mu \mathrm{L} \mathrm{L}^{-1}$ ), respectively, of each pesticide were as follows: chlorothalonil $(2.4,2.8,6.0)$; fipronil $(12.3,13.9,29.1)$; diazinon $(38.0,40.8$, $54.7)$; imidacloprid $(263,273,347)$; and propiconazole $(269,330,1008)$. These toxicity thresholds are higher than reported concentrations in monitoring programs; however, these data will contribute to improving water quality guideline values, which inform the total risk assessments posed by complex contaminant mixtures to which these pesticides contribute.

\section{Introduction}

\section{Pesticides in tropical marine waters}

Tropical marine ecosystems are under intense pressure from global climate change (Hughes et al. 2018), compounded by local pressures, including poor water quality from coastal development (Heery et al. 2018; Waterhouse et al. 2012). In Singapore, for example, the average water visibility has decreased from $10 \mathrm{~m}$ to $2 \mathrm{~m}$ due to sediment input from land reclamation and coastal development (Heery et al. 2018). Intensive coastal agriculture also poses a growing threat to tropical marine ecosystems worldwide, with models predicting that by 2050 about 1 billion ha of additional land would need to be converted into agriculture to 
meet global demands (Laurance et al. 2014). Tropical marine habitats off the coast of Nicaragua are severely degraded due to land clearing of coastal forest cover leading to increased sedimentation and degrading water quality (Jameson et al. 2019). Likewise, the coastal ecosystems of Malaysia are under continued threat by land reclamation and domestic and industrial waste pollution (Sany et al. 2019). In Australia more than $80 \%$ of the Great Barrier Reef (GBR) catchment area supports some form of agriculture (Gilbert \& Brodie 2001), which is dominated by sugarcane cultivation near the coast (Lewis et al. 2009; Waterhouse et al. 2012). Wet-season runoff from agricultural and urban development activities has reduced the water quality of the GBR over successive decades (Furnas 2003; Waterhouse et al. 2012). Along with elevated sediment and nutrients, pesticides (herbicides, insecticides and fungicides) from agricultural industries represent ongoing hazards to ecosystems of the nearshore GBR lagoon (O'Brien et al. 2016; RWQIP 2018). The GBR represents one of the most comprehensively monitored tropical marine systems with respect to pesticides, and it has been estimated that over 17,000 kg of the six most widely applied Photosystem II (PSII) herbicides (ametryn, atrazine, diuron, hexazinone, simazine and tebuthiuron) enter the GBR annually (Brodie et al. 2017). A recent study by Warne et al. (2020) analysed over 2600 water samples from 15 waterways that enter the GBR lagoon and found $99.8 \%$ of the samples had detectable concentrations of pesticides and pesticide mixtures.

\section{Alternative pesticides in the GBR}

Successive Australian government programs have aimed to reduce the loads of pesticides entering waters of the GBR and its catchments (Brodie et al. 2017; RWQIP 2018). At the same time, there have been changes in regulations and registration for pesticide application in coastal agriculture (Davis et al. 2014), leading to shifts in usage patterns and to at least 44 "alternative" pesticides being detected in the GBR catchments and lagoon (King et al. 2013; O'Brien et al. 2016). For example, the insecticides chlorothalonil, fipronil and propiconazole have been detected in the catchments while imidacloprid and diazinon have been found in both the catchments and GBR lagoon (Devlin et al. 2015; O'Brien et al. 2014). More specifically, imidacloprid is the most frequently detected insecticide in the GBR lagoon, being present in 
over half of the samples (50.3\%) that were analysed for this insecticide between 2011 and 2015 (Warne et al. 2020). Currently, fipronil is not included in the pesticide analytical suite for marine samples by the Great Barrier Reef Marine Park Authority Marine Monitoring Program (GBRMPA MMP) (Gallen et al. 2019); however, it is used in the catchments and should be included in future monitoring of marine samples. With the continued improvement of detection methods, it is likely that additional pesticides will be detected in tropical marine waters in the future (Devlin et al. 2015).

\section{Guidelines for alternative pesticides}

Monitoring and reporting concentrations of pesticides in tropical marine waters represents an important contribution to effectively manage long-term reductions in pesticide concentrations and loads (Brodie et al. 2017). However, to successfully assess the risks to tropical marine ecosystems we also need to understand the toxicity threshold for each pesticide to both the individual species (especially key habitat builders, such as corals) and to marine communities. In Australia, the preferred method to establish water quality guidelines for assessing risk involves the development of species sensitivity distributions (SSDs) from individual toxicity thresholds for multiple species representing a community (Belanger et al. 2016). The criteria for developing the guidelines have recently been updated in the Australian context and are comprehensively described in Warne et al (2018a). However, many of the alternative pesticides have not been provided Default Guideline Values (DGVs) in the current Australian and New Zealand water quality guidelines (ANZG 2018). To address this, new guideline updates were proposed for 27 GBR-relevant pesticides based on all recent available data (King et al. 2017a; King et al. 2017b; Warne et al. 2018b); however, many of these values are of low reliability due to lack of toxicity data. Furthermore, the vast majority of data used in the derivation of water quality guidelines have been sourced from tests using temperate and freshwater species (ANZG 2018; King et al. 2017a; King et al. 2017b). Clearly, more toxicity data are needed for relevant tropical species to inform the development of water quality guidelines and risk assessments for pesticides that have been detected in sensitive tropical marine habitats.

\section{Effects of pesticides on corals}


96

97

98

99

100

101

102

103

104

105

106

107

108

109

110

111

112

113

114

115

116

117

118

119

120

121

122

123

Corals represent the key habitat-forming species of tropical coral reefs and can be found adjacent to coastal agriculture in the GBR (Gilbert \& Brodie 2001; Thorburn et al. 2013) and globally (Donner \& Potere 2007; Salvat 1992). The effects of PSII herbicides on corals primarily impact the photosynthetic capacity of coral symbionts, leading to the breakdown of this symbiosis (bleaching) (Jones 2005; Jones \& Kerswell 2003; Negri et al. 2011a; Owen et al. 2002). This breakdown can have flow-on effects, such as reduced reproductive output (Cantin et al. 2007). The effects of insecticides and fungicides on corals are far less studied and are more likely to affect the animal host directly, including the sensitive early life transitions and stages, such as fertilisation, attachment and metamorphosis of planulae larvae into sessile polyps (van Dam et al. 2011). Markey et al. (2007) examined the effects of insecticides and a fungicide on coral fertilisation and larval metamorphosis. The fungicide MEMC inhibited fertilisation and metamorphosis success at concentrations as low as $1 \mu \mathrm{g} \mathrm{\textrm {L } ^ { - 1 }}$. While fertilisation was not affected by any of the insecticides (chlorpyrifos, profenofos, endosulfan and permethrin) at concentrations up to $30 \mu \mathrm{g} \mathrm{L}^{-1}$, metamorphosis was more sensitive to the insecticides, which was inhibited at insecticide concentrations as low as $3 \mu \mathrm{g} \mathrm{L}-1$. Acevedo (1991) reported mortality in Pocillopora damicornis larvae exposed to chlorpyrifos and carbaryl at much higher concentrations ( 1 and $100 \mathrm{mg} \mathrm{L}^{-1}$, respectively) but did not test effects on larval function (i.e. attachment and metamorphosis). The organophosphate insecticide naled (Dibrom) reduced the survival of larvae of Porites astreoides at $3 \mu \mathrm{g} \mathrm{L}-1$ while permethrin had no effect on larval survival or metamorphosis at up to $6 \mu \mathrm{g} \mathrm{L}^{-1}$ (Ross et al. 2015). The tissues of juvenile $A$. tenuis became partially detached when exposed to the organophosphate dichlorvos at concentrations of $1000 \mu \mathrm{g} \mathrm{L}^{-1}$ (Watanabe et al. 2006), a response similar to "polyp bailout", previously reported as a stress response of stony corals to escape distressing and unfavourable conditions (Sammarco 1982). Only three studies have tested the effects of insecticides on adult corals. The first used a commercial formulation of chlorpyrifos and reported coral mortality at $6 \mu \mathrm{g} \mathrm{L}^{-1}$ of the active ingredient (Te 1998). Negri et al. (2009) found no effects of the biological insecticide Bacillus thuringiensis on adult and larval corals and sponges at $5000 \mathrm{\mu g} \mathrm{L}^{-1}$. A recent study from Wecker and colleagues (2018) reported that the organochlorine insecticide chlordecone caused 
124 adult Pocillopora damicornis branchlets to release their polyps after $96 \mathrm{~h}$ exposure to $30 \mu \mathrm{g} \mathrm{L}^{-1}$

125 (again similar to "polyp bailout").

126 In total, the toxicity of eight insecticides and one fungicide have been assessed on coral larvae

127 but, few of these toxicity data meet the experimental criteria required for inclusion into

128 national water quality guidelines ((Warne et al. 2018a) e.g. did not use pure compounds, did

129 not measure dissolved pesticide concentrations, etc.). In order to improve water quality

130 guidelines and subsequent risk assessments for pesticides in tropical marine ecosystems, the

131 aim of this current study was to identify the toxicity thresholds of three insecticides (diazinon,

132 fipronil, imidacloprid) and two fungicides (chlorothalonil and propiconazole), which have been

133 detected in the GBR lagoon or catchments, on larval metamorphosis of the common reef-

134 building coral Acropora tenuis larvae following $48 \mathrm{~h}$ exposures.

\section{Materials \& Methods}

\section{7}

138

139

140

141

142

143

144

145

146

147

148

149

150

\section{Sample collection and larval culture}

Gravid colonies (25-40 cm diameter) of the coral Acropora tenuis (Dana, 1846) were collected from 4-8 m depth on two occasions: in November 2016 from Trunk Reef $\left(18^{\circ} 18.2^{\prime} \mathrm{S}, 146^{\circ} 52.2^{\prime}\right.$ E) and in November 2017 from Falcon Island (18 46' S, 146 $32^{\prime}$ E), GBR under GBRMPA Permit G12/35236.1. Colonies were transported to the National Sea Simulator (SeaSim) at the Australian Institute of Marine Science (AIMS) in Townsville and maintained in $1700 \mathrm{~L}$ flowthrough holding tanks until spawning. Temperatures were held at $26-27^{\circ} \mathrm{C}$, which was equivalent to the water temperature at the collection sites. Gametes, on both occasions, were collected from eight parental colonies, fertilised and symbiont-free larvae were cultured at approximately 500 larvae L-1 in 500 L flow-through tanks (Negri \& Heyward 2001; Nordborg et al. 2018). Larvae (each 800-1000 $\mu \mathrm{m}$ in length) were competent to undergo attachment and metamorphosis after $5 \mathrm{~d}$ and we applied 10-day-old A. tenuis larvae on the first occasion and 7day-old larvae on the second occasion in pesticide exposure experiments. Metamorphosis was defined here as the change in life stage from free swimming or casually attached sausage- 
151 shaped larvae (Fig. 1A) to squat, firmly attached, disc-shaped structures with pronounced

152 flattening of the oral-aboral axis and with septal mesenteries radiating from the central mouth

153 region (Fig. 1B) (Heyward \& Negri 1999). All pesticides were included in the first experiment;

154 however, minimal inhibition was observed at the highest propiconazole concentration tested.

155 Therefore, a second experiment was run the following year with higher propiconazole

156 concentrations, reference copper and seawater and solvent controls.

157

158

159

160

161

162

163

164

165

166

167

168

169

170

171

172

173

174

175

176

177

\section{Pesticides}

The five pesticides in this study represent three chemical classes of insecticides and two classes of fungicides (See Table 1). All pesticides were analytical grade (>98\% purity) and purchased from Sigma-Aldrich (NSW, Australia). Stock solutions $\left(5 \mathrm{mg} \mathrm{L}^{-1}\right)$ of all pesticides were dissolved in dimethyl sulfoxide (DMSO, $0.01 \% \mathrm{v} / \mathrm{v}$ ) and prepared in milli- $\mathrm{Q}^{\circledR}$ water. $A$. tenuis larvae were exposed to measured concentrations of diazinon $\left(2.6-638 \mu \mathrm{g} \mathrm{L}^{-1}\right)$, fipronil $\left(1.1-1144 \mu \mathrm{g} \mathrm{L}^{-1}\right)$, imidacloprid $\left(3.8-947 \mu \mathrm{g}^{-1}\right)$, propiconazole $\left(7.9-1975 \mu \mathrm{g} \mathrm{L}^{-1}\right)$ and chlorothalonil $(0.5-507 \mu \mathrm{g}$ $\left.\mathrm{L}^{-1}\right)$. A table with the measured concentrations of each pesticide can be found in eAtlas (2020).

\section{Metamorphosis assays}

Static exposures were conducted in $20 \mathrm{~mL}$ clear glass scintillation vials containing 12-14 larvae made up to $10 \mathrm{~mL}$ filtered seawater $(0.5 \mu \mathrm{m})$ with 6-7 concentrations (per pesticide) and six replicate vials per concentration. All tests included solvent controls containing identical concentrations of DMSO carrier. Seawater and solvent carrier controls were run in 12-18 replicate vials. Copper $\left(\mathrm{CuCl}_{2}\right)$ was used as a reference toxicant at six measured concentrations between 1.1-35 $\mathrm{mg} \mathrm{L}^{-1}$ and six replicate vials per concentration.

Glass vials were transferred in random positions within a refrigerated shaking incubator (TLM530, Thermoline Scientific) at 70 RPM to maintain gentle water movement which prevented larvae from attaching and undergoing metamorphosis in the containers (Negri et al., 2016). Larvae were exposed under a light intensity of approximately $60 \mu \mathrm{mol}$ photons $\mathrm{m}^{-2} \mathrm{~s}^{-1}(12: 12 \mathrm{~h}$ light:dark cycle) and at a temperature of $26.7 \pm 0.3^{\circ} \mathrm{C}$ (mean $\pm \mathrm{SE}$ ). Vials were re-randomised at $24 \mathrm{~h}$. After $48 \mathrm{~h}$ exposure larvae and corresponding treatment water were transferred in the 
178 same seawater into untreated 6-well polystyrene culture plates (Nunc, NY, USA) and returned

179 to the incubator for an additional $24 \mathrm{~h}$ but without water movement. Metamorphosis was

180 initiated by the addition of crustose coralline algae (CCA) extract (10 $\mu \mathrm{L})$ prepared from $4 \mathrm{~g}$ CCA

181 Porolithon onkodes (Heyward \& Negri 1999; Negri et al. 2005). Metamorphosis was assessed

182 after a further $24 \mathrm{~h}$ and considered normal if larvae had undergone irreversible attachment to

183 the well plate and had undergone metamorphosis into a polyp form as described above. All

184 other larvae (swimming, casually attached, dead and partially disintegrated) were classed as

185 not metamorphosed. Average metamorphosis success $\geq 70 \%$ in controls was considered

186 indicative of a standard response to metamorphosis inducers based on several previous studies

187 using CCA or extracts of CCA to initiate metamorphosis in coral larvae (Negri et al. 2016; Negri

188 et al. 2011b; Negri \& Heyward 2000).

\section{Chemical analysis and water quality}

190

191

192

193

194

195

196

197

198

199

200

201

202

203

204

205

Analytical samples (2-3 samples per pesticide including solvent control) were measured at initiation and termination of experiment. Aliquots $(1 \mathrm{~mL})$ were transferred into $1.5 \mathrm{~mL}$ liquid chromatography amber glass vials and spiked with surrogate standards (i.e. diazinon-d10, 13C4fipronil, imidacloprid-d4, propiconazole-d5 (stock solution of $1 \mu \mathrm{g} \mathrm{mL}^{-1}$ ). The final concentration of the surrogate standard was $10 \mathrm{ng} \mathrm{mL}^{-1}$. The measured concentrations for remaining treatments were calculated based on a linear relationship between nominal and the time weighted average (time $=0$ and $48 \mathrm{~h}$ ) of measured concentrations. All pesticide analyses (except for chlorothalonil) were performed at the Queensland Alliance for Environmental Health Sciences (QAEHS), The University of Queensland using HPLC-MS/MS (SCIEX Triple QuadTM 6500 QTRAP $^{\circledR}$ mass spectrometer Shimadzu Nexera X2 uHPLC system) (Mercurio 2016; Mercurio et al. 2015). Queensland Health Forensic and Scientific Services (NATA accreditation No. 41) measured chlorothalonil samples and an external calibration was used for chlorothalonil, so no internal standard was used.

Physico-chemical parameters ( $\mathrm{pH}$, salinity and dissolved oxygen) were measured in clear glass containers $(60 \mathrm{~mL})$ with approximately 60 larvae in $50 \mathrm{~mL}$ filtered seawater using three to six concentrations per pesticide (including controls). Containers were placed alongside 
206

207

208

209

210

211

212

213

214

215

216

217

218

219

220

221

222

223

224

225

226

227

228

229

230

231

experimental vials, and physico-chemical parameters were measured at the start and $48 \mathrm{~h}$ postexposure. Temperature was logged at 5 min intervals (HOBO pendant 64K data logger, Onset Computer Corp, USA). Salinity and pH were measured via a handheld meter (Horiba LAQUAact PC110, Hach, USA) and dissolved oxygen concentration was determined with a handheld meter (HQ30d equipped with Intellical LDO101 oxygen probe, Hach, USA). Physico-chemical parameters (mean $\pm \mathrm{SE}, \mathrm{n}=60$ ) were met throughout the experimental period: temperature $\left(26.7 \pm 0.3^{\circ} \mathrm{C}\right)$, dissolved oxygen (>98\% mean saturation, $\left.8.1 \pm 0.03 \mathrm{mg} \mathrm{L}^{-1}\right)$, salinity $(36 \pm 0.2$ psu) and $\mathrm{pH}(8.17 \pm 0.01)$. All data can be found in eAtlas (2020).

\section{Data analysis}

No effect concentrations (NECS) and effect concentrations, i.e. concentrations of each pesticide that inhibited $10 \%$ and $50 \%$ of $A$. tenuis larval metamorphosis relative to controls $\left(\mathrm{EC}_{10}\right.$ and $\mathrm{EC}_{50}$, respectively), were calculated from the proportion of metamorphosed larvae as a function of log measured concentration of each pesticide. NECs are the preferred statistical estimate of chronic toxicity for guideline value (GV) derivation (Fox 2010; Warne et al. 2018a). Bayesian binomial segmented-regression models were applied to the data using the package jagsNEC (Fisher et al. 2019) in R 3.5.3 (R Core Team 2017), and the model fits were evaluated using trace plots and fitted vs. residual plots. For diazinon, fipronil, chlorothalonil and copper, Bayesian beta segmented-regression models provided better fits and were applied. Models were run using uninformative priors, with 10,000 Markov chain Monte Carlo (MCMC) iterations after an initial 'burn-in' period of 20,000 iterations for five separate chains. See Thomas et al. (2020) for further details. Graphical outputs were generated in R.

\section{Results}

\section{Larval metamorphosis assays}

Metamorphosis success for 7-day-old larvae in solvent control treatments was $72.2 \pm 6.1 \%$ (mean \pm SE) and this was not statistically different from the $75.9 \pm 4.8 \%$ achieved in seawater 
232 controls (student's t-test: $p=0.641$ ). Ten-day-old larval metamorphosis success was similar:

$23372.6 \pm 3.7 \%$ in solvent control treatments and $77.5 \pm 3.6 \%$ in seawater controls (student's t-

234 test: $p=0.366)$.

235 Larvae from most treatments exhibited normal swimming behaviour after 24 and $48 \mathrm{~h}$ (not

236 quantified). However, some coral larvae exposed to $17.4 \mu \mathrm{g} \mathrm{L}-1$ copper and $56.3 \mu \mathrm{g} \mathrm{L}^{-1}$

237 chlorothalonil (Fig. 1D) were not swimming after $24 \mathrm{~h}$ and $48 \mathrm{~h}$, respectively. Larvae exposed to

$23834.9 \mu \mathrm{g} \mathrm{L}-1$ copper and $169 \mu \mathrm{g} \mathrm{L}^{-1}$ chlorothalonil (and above) disintegrated. Larvae exposed to all

239 other contaminants remained intact and were moving. All pesticides, and the reference

240 toxicant copper, inhibited metamorphosis of $A$. tenuis larvae as concentrations increased,

241 enabling the fitting of concentration-response relationships (Fig. 2). Chlorothalonil was the

242 most potent pesticide towards $A$. tenuis metamorphosis with an $\mathrm{EC}_{10}$ of $2.8 \mu \mathrm{g} \mathrm{\textrm {L } ^ { - 1 }}$ and a NEC of

$2432.4 \mu \mathrm{g} \mathrm{L}^{-1}$ while propiconazole was the least toxic with an $\mathrm{EC}_{10}$ of $330 \mu \mathrm{g} \mathrm{L}^{-1}$ and an NEC of 269

$244 \mu \mathrm{g} \mathrm{L}^{-1}$ (Table 2, Fig. 1C). The relative order of pesticide toxicity according to the calculated $\mathrm{EC}_{50} \mathrm{~S}$

245 was: chlorothalonil > fipronil > diazinon > imidacloprid > propiconazole (Table 2).

246

247 Discussion

248 All pesticides negatively affected coral larval metamorphosis into a sessile polyp. The success of

249 this early life transition is a critical step in the recruitment process of corals leading to

250 population maintenance and recovery following disturbance (Harrison \& Wallace 1990);

251 therefore, inhibition of metamorphosis success is a key endpoint of ecological relevance for

252 assessing risk to coral reef communities. This study is among the first to derive insecticide and

253 fungicide toxicity thresholds for coral that are suitable for national water quality guideline value

254 (WQGV) derivation, revealing differences in toxicity across two orders of magnitude among

255 pesticides (NEC of $2.4 \mu \mathrm{g} \mathrm{L}^{-1}$ for the broad-spectrum fungicide chlorothalonil to a NEC of $263 \mu \mathrm{g}$

$256 \mathrm{~L}^{-1}$ for the insecticide imidacloprid). The specificity of the modes of action of these pesticides

257 provide guidance for assessing their potential to impact non-target species, such as corals.

258 Insecticides and fungicides are designed to affect insects or fungi; however, they can also

Peer) reviewing PDF | (2020:05:48551:2:0:NEW 1 Jul 2020) 
259 become toxic to non-target species (such as corals) in several ways including: (i) if coral shares

260 the same receptor/target that the pesticide is designed to affect; (ii) if other specific pathways

261 or cellular processes are inadvertently affected, or (iii) by non-specific narcosis, where

262 hydrophobic contaminants can accumulate in cell membranes and affect structure and function

263 (Verhaar et al. 1992). The bioassays were applied on 7- and 10-day-old coral larvae, which at

264 this point in their development were motile (propelled by cilia) and competent to settle (had

265 developed all the cellular structures necessary to detect a chemical cue that initiates

266 metamorphosis into a sessile polyp) (Babcock \& Heyward 1986; Heyward \& Negri 1999). It is

267 possible that the pesticides which are toxic at low concentrations may directly affect larval

268 biochemistry, including the cellular signalling and processes of metamorphosis. Even if the coral

269 does not have a pesticide-specific target, a hydrophobic pesticide may elicit narcotic toxicity at

270 higher concentrations, with more hydrophobic compounds (measured by the partitioning

271 coefficient between octanol and water, $\mathrm{K}_{\mathrm{ow}}$ ) able to accumulate to a greater degree in lipid

272 membranes and cause greater narcotic toxicity (Di Toro et al. 2000).

273 The following sections compare the mechanisms of action of the pesticides tested with

274 cnidarian biochemistry and the sensitivity we found in the larval metamorphosis assays. This

275 allowed us to consider the possibility that larvae were affected by the primary modes of action

276 of each pesticide.

\section{Diazinon}

278 Diazinon affected metamorphosis success of $A$. tenuis coral larvae at relatively low

279 concentrations (NEC: $38.0 \mu \mathrm{g} \mathrm{L}^{-1}$; Table 2). Organophosphate pesticides, like diazinon, inhibit

280 acetylcholinesterase (AChE), an enzyme involved in the breakdown of the chemical

281 acetylcholine (ACh)(Cox 2000; Garber \& Steeger 2008). Inhibition of AChE leads to an

282 accumulation of $\mathrm{ACh}$, which results in hyperstimulation and disrupted neurotransmission.

283 Cnidarians, including Hydrozoa and Anthozoa such as corals, possess ACh (Horiuchi et al. 2003;

284 Kass-Simon \& Pierobon 2007; Talesa et al. 1992), representing some of the first indications of a

285 neural net in this primitive phylum. Several studies have shown that ACh is involved in cnidarian

286 neurotransmission; however, whether the chemical acts as a neuromodulator or

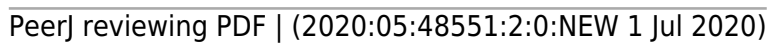


287 neurotransmitter is unclear (Faltine-Gonzalez \& Layden 2019; Kass-Simon \& Pierobon 2007).

288 Morgan and Snell (2002) demonstrated the specific induction of esterase gene in the coral

289 Acropora cervicornis when exposed to the AChE inhibitor mosquitocide Dibrom. The toxicity of

290 diazinon to coral larvae adds to evidence that AChE inhibitors, including the organophosphate

291 chlorpyrifos (Acevedo 1991; Markey et al. 2007) and Dibrom (Ross et al. 2015), are toxic to

292 corals. Chlorpyrifos has been shown to disrupt swimming behaviour of larval Pocillopora

293 damicornis at $100 \mu \mathrm{g} \mathrm{L}^{-1}$ and a 50-100\% larval mortality at $1000 \mu \mathrm{g} \mathrm{L}^{-1}$ (Acevedo 1991) while

294 adult coral $P$. damicornis were sensitive to effluent water from soil treated with chlorpyrifos

295 with a 96-h LC 50 of $6 \mu \mathrm{g} \mathrm{L}^{-1}$ (Te 1998). Ross et al (2015) found that Dibrom as low as $2.96 \mu \mathrm{g} \mathrm{L}^{-1}$

296 inhibited larval metamorphosis of the coral Porites astreoides. In this study, $A$. tenuis larvae

297 exhibited a similar sensitivity to diazinon as the shrimp Penaeus duorarum and sea urchin

298 Paracentrotus lividus (21 $\mathrm{g} \mathrm{L}^{-1} \mathrm{LC}_{50}, 30 \mu \mathrm{g} \mathrm{L} \mathrm{L}^{-1} \mathrm{LOEC}$, respectively; Table 3 (Pesando et al. 2003;

299 Sunderam et al. 2000)). Diazinon concentrations in the GBR catchments and coastal waters

300 have been detected up to $0.7 \mathrm{ng} \mathrm{L}^{-1}$ (O'Brien et al. 2014) which exceeds the $99 \%$ species

301 protection guideline value of $0.03 \mathrm{ng} \mathrm{L}^{-1}$ in freshwater systems (Table 4). Due to very limited

302 published marine toxicity data for diazinon, there are no reliable guideline values for diazinon in

303 marine ecosystems. Therefore, current WQGVs for diazinon in marine waters uses the

304 freshwater guideline protective concentrations, and these would be protective of coral larval

305 metamorphosis.

306

307

308

309

310

311

312

313

314

Fipronil

Fipronil, belonging to the phenylpyrazole family, is a systemic insecticide which blocks the GABA-regulated chloride channel in neurons, particularly in insects (Anadon \& Gupta 2012;

Gunasekara et al. 2007; Stenersen 2004). GABA itself has been found to be involved in cnidarian neurotransmission (Kass-Simon \& Pierobon 2007) and several neurotransmitters have been shown to induce larval metamorphosis (Moeller et al. 2018). Crustaceans are one of the most highly sensitive non-target groups to fipronil exposure, which is expected as they belong to the same phylum as insects (Arthropoda). For example, fipronil has been shown to affect survival (20\% mortality) of adult female grass shrimp Palaemonetes pugio at concentrations as low as 
$3150.2 \mu \mathrm{g} \mathrm{L}^{-1}$ (see Table 3) (Volz et al. 2003). While A. tenuis larvae were not as sensitive to fipronil

316 (NEC $10: 12.3 \mu \mathrm{g} \mathrm{L}^{-1}$ ) as grass shrimp, this was the most toxic insecticide of the three insecticides

317 tested to corals in the present study. Interruption of neurotransmission (and motor control

318 processes) by affecting coral larval chloride channels is a plausible mode of action for fipronil

319 that should be investigated further. While fipronil is not usually included in the analysis suite for

320 marine sample monitoring (e.g. GBRMPA MMP), it has been detected at "very low"

321 concentrations in GBR catchments (Gallen et al 2019). However, due to the low frequency of

322 detections (and detected concentrations) in GBR catchments, it is unlikely at present that

323 fipronil substantially contributes to the overall pesticide toxicity risk in GBR marine waters. The

324 proposed 99\% species protection guideline value (PGV) for fipronil in marine waters is 0.0034

$325 \mu \mathrm{g} \mathrm{L^{-1 }}$ (Table 4) which is below the limit of reporting level of $0.02 \mu \mathrm{g} \mathrm{L}^{-1}$ by the GBRMPA MMP

326 and would protect coral larval metamorphosis.

327

328

329

330

331

332

333

334

335

336

337

338

339

340

341

342

\section{Imidacloprid}

Imidacloprid was the least toxic insecticide to $A$. tenuis larvae in the present study. Imidacloprid is a neonicotinoid that irreversibly binds to postsynaptic nicotinic acetylcholine receptors (nAChRs), interfering with neural transmission (Abbink 1991; Plumlee 2004). More specifically, imidacloprid has a narrow specificity for a unique binding subsite of insect nAChRs (Casida \& Quistad 2004; Tomizawa \& Casida 2005). Therefore, even though nAChRs have been well described in cnidarians (Anctil 2009; Chapman et al. 2010; Faltine-Gonzalez \& Layden 2019), imidacloprid's selectivity for insect nicotinic receptors suggests toxicity of imidacloprid to corals may instead be due to general narcotic toxicity which increases with its ability to accumulate in lipid membranes (Verhaar et al. 1992). However, imidacloprid has a very low log $\mathrm{K}_{\text {ow }}(0.57)$ indicating low hydrophobicity and is unlikely to bioaccumulate in the lipid membranes of animals. It is unclear whether narcotic toxicity contributed to the effects on coral larvae at the high concentrations of imidacloprid observed here. While there are limited toxicity data for marine species, the blue crab Callinectes sapidus megalopae was more than an order of magnitude more sensitive to imidacloprid with an $\mathrm{LC}_{50}$ of $10 \mu \mathrm{g} \mathrm{L}^{-1}$ compared to $A$. tenuis coral larvae with an $\mathrm{EC}_{10}$ of $263 \mu \mathrm{g} \mathrm{L}^{-1}$ (see Table 3). In contrast, imidacloprid was found to be virtually 
343

344

345

346

347

348

349

350

351

352

353

354

355

356

357

358

359

360

361

362

363

364

365

366

367

368

369

370

non-toxic to Artemia sp. with an $\mathrm{LC}_{50}$ of $361,000 \mu \mathrm{g} \mathrm{L}-1$ (see Table 3). Several recent studies revealed sublethal effects of low concentrations $\left(5 \mu \mathrm{g} \mathrm{L}^{-1}\right)$ of imidacloprid on marine species, including reduced lipid content and weight, in the shrimp Penaeus monodon over $21 \mathrm{~d}$ exposures (Butcherine et al. 2020). Sublethal effects of $10 \mu \mathrm{g} \mathrm{L}^{-1}$ imidacloprid over $14 \mathrm{~d}$ exposures also affected enzyme activity and fatty acid composition in the Sydney rock oysters Saccostrea glomerata (Ewere et al. 2019). Imidacloprid has been detected at concentrations as high as $1.5 \mu \mathrm{g} \mathrm{L}^{-1}$ in groundwater samples (Devlin et al. 2015) and up to $0.09 \mu \mathrm{g} \mathrm{L}^{-1}$ in marine samples (O'Brien et al. 2015) which exceed the proposed PC99 guideline value (PGV) of 0.057 $\mu \mathrm{g} \mathrm{L}^{-1}$ (Table 4). The PGVs for imidacloprid (Table 4) would be protective for coral larval metamorphosis; however, these PGVs values use a mixture of both marine and freshwater ecotoxicity data so more data are needed to develop higher reliability WQGVs for marine organisms.

\section{Chlorothalonil}

Chlorothalonil was the most toxic of the five pesticides tested in this study to coral larvae with a NEC of $2.42 \mu \mathrm{g} \mathrm{L}^{-1}$. Chlorothalonil is a non-systemic organochlorine that binds and depletes the antioxidant glutathione (Cox 1997; Raman 2014; Tillman et al. 1973), which is found in animals, plants, fungi and some bacteria (Alanazi et al. 2015). Chlorothalonil (266 $\mathrm{g} \mathrm{L}^{-1}$ ) has been shown to reduce haemocyte functionality (by altering morphology of phagocytes) and apoptosis of blood cells of the tunicate Botryllus schlosseri (Cima et al. 2008). Depletion of antioxidants (e.g. glutathione) can lead to oxidative stress, subsequently causing cell damage and death (Cima et al. 2008; Palmer \& Traylor-Knowles 2018). Therefore, it is plausible that a reduction in the antioxidant glutathione impeded larval metamorphosis of $A$. tenuis by interfering with its cellular metabolism. We also observed adverse swimming behaviour of the coral larvae at 56.3 $\mu \mathrm{g} \mathrm{L^{-1 }}$ chlorothalonil and disintegration at $\geq 169 \mu \mathrm{g} \mathrm{L}^{-1}$. A similar negative effect was also recognised by Markey (2007), whereby the fungicide MEMC caused coral larvae to stop swimming at concentrations $\geq 3 \mu \mathrm{g} \mathrm{L}^{-1}$. In addition, the breakdown product of chlorothalonil, 4hydroxy-2,5,6-trichloroisophthalonitrile (not quantified in the present study), has the potential to be more toxic than the parent compound (Cox 1997). Chlorothalonil is considered a pesticide 
371 of interest due to its application within GBR catchments even though chlorothalonil has been

372 detected at only very low concentrations (Devlin et al. 2015; Holligan et al. 2017). The PGV

373 PC99 of chlorothalonil at $0.34 \mu \mathrm{g} \mathrm{L}^{-1}$ (Table 4) would be protective of coral larval

374 metamorphosis.

\section{Propiconazole}

376 Coral larvae were not as sensitive to the fungicide propiconazole, with a NEC of $269 \mu \mathrm{g} \mathrm{L}^{-1}$, a

377

378

379

380

381

382

383

384

385

386

387

388

389

390

391

392

393

394

395

396

397

398

concentration highly unlikely to be detected in tropical marine waters. Propiconazole inhibits ergosterol synthesis (USEPA 2006), which is a sterol found in fungi but absent in animals, suggesting another mechanism by which propiconazole interferes with coral larval metamorphosis at high concentrations. Studies have shown potential adverse effects of conazoles on CYP-mediated process in non-target species. For example, propiconazole has been found to interfere with the production of estrogen (lyer \& Makris 2010) and embryonic development in the crustacean Daphnia magna (Kast-Hutcheson et al. 2001). Long term exposure ( $\geq 20 \mathrm{~d}$ ) to propiconazole $\left(\geq 50 \mu \mathrm{g} \mathrm{L}^{-1}\right)$ has also been shown to cause oxidative stress in liver, gill and muscle tissues of rainbow trout Oncorhynchus mykiss (Li et al. 2010). Li et al (2010) also reported an increase in lipid peroxidation in O. mykiss after exposure with propiconazole. Coral planula larvae contain large quantities of lipid (Richmond 1987) and propiconazole may interfere with larval metamorphosis by attacking membrane lipids. Narcotic toxicity is a more likely mechanism here than for imidacloprid as propiconazole is relatively hydrophobic (log Kow of 3.72) suggesting that propiconazole may accumulate in cell membranes affecting structure and function (Di Toro et al. 2000). The toxicity of propiconazole is also relatively low for other aquatic species but can be highly dependent on the duration of exposure. After $48 \mathrm{~h}$ exposure to propiconazole, the $\mathrm{LC}_{50}$ of $D$. magna was $9000 \mu \mathrm{g} \mathrm{L}^{-1}$ but this dropped to $180 \mu \mathrm{g} \mathrm{L} \mathrm{L}^{-1}$ after $96 \mathrm{~h}$ exposure (Ochoa-Acuña et al. 2009). A study by BetancourtLozano et al. (2006) found a 24-h LC 50 of $1167 \mu \mathrm{g} \mathrm{L}^{-1}$ for juvenile Pacific white shrimp Litopenaeus vannamei. Propiconazole has recently been detected in marine samples by the GBRMPA MMP but at very low concentrations < $0.001 \mu \mathrm{g} \mathrm{L}^{-1}$ (Gallen et al. 2019), not exceeding the PGVs (Table 4) which would be protective of coral larval metamorphosis.

PeerJ reviewing PDF | (2020:05:48551:2:0:NEW 1 Jul 2020) 


\section{Copper}

400 The inhibition of $A$. tenuis larval metamorphosis success by the reference toxicant $\mathrm{Cu}$ (II) after

$40148 \mathrm{~h}\left(\mathrm{EC}_{50}: 10.2 \mu \mathrm{g} \mathrm{L}^{-1}\right)$ was similar to previous studies using the same species, $32 \mu \mathrm{g} \mathrm{L}^{-1}\left(\mathrm{EC}_{50}\right)$

402 after $24 \mathrm{~h}$ (Negri \& Hoogenboom 2011) and $35 \mu \mathrm{L} \mathrm{L}^{-1}\left(\mathrm{EC}_{50}\right)$ after $48 \mathrm{~h}$ (Reichelt-Brushett \&

403 Harrison 2000), and to other coral species, including Acropora aspera $\left(\mathrm{EC}_{10}: 5.8 \mu \mathrm{g} \mathrm{L}^{-1}\right)$ and

404 Platygyra daedala ( $\mathrm{EC}_{10}: 16 \mu \mathrm{g} \mathrm{L}-1$ ) (Gissi et al. 2017), validating the sensitivity and suitability of

405 the test. The NEC for $\mathrm{Cu}$ (II) in the present study was $7.4 \mu \mathrm{g} \mathrm{L}^{-1}$, which is between the P90 and

406 P80 WQGVs for copper in marine waters (ANZQ 2018), indicating the inhibition of larval

407 metamorphosis in this species is relatively sensitive in comparison with other taxa. Although

408 copper is an essential element to life at background concentrations, it has a wide range of toxic

409 actions at higher concentrations, including blocking biological functional groups of proteins and

410 enzymes, displacing other essential metal ions and modifying the confirmation of biomolecules

411 (Eisler 1998). The specific impacts of Cu (II) on larval metamorphosis are unknown but may

412 affect larval function, including mobility, as observed for coral Goniastrea aspera by Reichelt-

413 Brushett \& Harrison (2004). More specifically, Cu (II) may affect signal transduction pathways

414 related to larval metamorphosis into sessile polyps (Negri \& Hoogenboom 2011).

Environmental relevance and conclusions

416

417

418

419

420

421

422

423

424

425

426

All five pesticides investigated here are commonly applied in agriculture within catchments of the GBR and were toxic to coral larval metamorphosis. While the toxicity thresholds (NECs and $\mathrm{EC}_{10} \mathrm{~S}$ ) were higher than measured or expected concentrations in tropical waters, these pesticides have the potential to contribute to overall risk posed by pesticide mixtures which are commonly detected in the environment (Gallen et al. 2019; Lewis et al. 2009; Warne et al. 2020). For instance, Key et al. (2007) found greater than additive toxicity to grass shrimp Palaemonetes pugio larvae when atrazine was added to a fipronil/imidacloprid mixture. The cumulative risks posed by co-occurring pesticides should be assessed by combining the total risks of all pesticides detected and this can be achieved by applying the multisubstancePotentially Affected Fraction (ms-PAF method) (Traas et al. 2002). The effects of pesticides on tropical species can also increase with other pressures common to tropical ecosystems and the 
427 ms-PAF method was recently extended to adjust WQGVs for pesticides to account for heatwave 428 conditions (Negri et al. 2020). ms-PAF has been applied in pesticide monitoring and reporting in 429 GBR waters and exceedances of WQGVs in GBR waters were more common when the 430 combined toxicity of multiple co-occurring herbicides was considered (Gallen et al. 2019). 431 However, high-reliability WQVGs that are necessary to predict ms-PAFs are not available for all 432 alternative pesticides. For example, diazinon is the only pesticide tested in this study with a 433 current Australian and New Zealand guideline (Table 4) and this was derived from temperate 434 freshwater species toxicity data. The proposed guideline values for the remaining four 435 pesticides tested in this study (Table 4) include more recent data but rely heavily on toxicity 436 thresholds of temperate freshwater species. Further studies are also needed on the toxicity of 437 their metabolites and transformation products which are also detected in the marine 438 environment, and can be more toxic than the parent compound (Mercurio et al. 2018; Sinclair 439 \& Boxall 2003). In addition, understanding the toxicities of commercial pesticide formulations need to be more thoroughly investigated as formulations have been found to increase toxic 441 responses in marine organisms (Devlin et al. 2015; Kroon et al. 2015). For example, Stoughton 442 (2006) found the imidacloprid-formulations were more toxic to the fresh/brackish water midge 443 Chironomus tentans and the amphipod Hyalella azteca than the technical grade imidacloprid.

444 The present study contributes toxicity thresholds for coral that can improve SSDs by the 445 inclusion of this key reef-building taxa, and this will in turn improve the relevance of WQGVs for 446 tropical marine ecosystems of high ecological value. 


\section{Acknowledgements}

448 The authors thank the staff at the AIMS National Sea Simulator for field collection assistance 449 and logistical support. The authors acknowledge the Manbarra, Bandjin and Bindal people as 450 the Traditional Owners where this work took place. We pay our respects to their elders past, 451 present and emerging and we acknowledge their continuing spiritual connection to their land 452 and sea country.

\section{References}

455

456

457

458

459

460

461

462

463

464

465

466

467

468

469

470

471

472

Abbink J. 1991. The biochemistry of imidacloprid. Agricultural Science and Technology Information 42:183-195.

Acevedo R. 1991. Preliminary observations on effects of pesticides carbaryl, napthol, and chlorpyrifos on planulae of the hermatypic coral Pocillopora damicornis. Pacific Science 45:287-289.

Al-Badran AA, Fujiwara M, Gatlin DM, Mora MA. 2018. Lethal and sub-lethal effects of the insectide fipronil on juvenile brown shrimp Farfantepenaeus aztecus. Scientific Reports 8(1):10769.

Alanazi AM, Mostafa GAE, and Al-Badr AA. 2015. Chapter Two - Glutathione. In: Brittain HG, ed. Profiles of Drug Substances, Excipients and Related Methodology: Academic Press, 43158.

Anadon A, and Gupta RC. 2012. Chapter 50 - Fipronil. Veterinary Toxicology (Second Edition):604-608. doi: 10.1016/B978-0-12-385926-6.00050-8.

Anctil M. 2009. Chemical transmission in the sea anemone Nematostella vectensis: A genomic perspective. Comparative Biochemistry and Physiology, Part D 4:268-289. doi: 10.1016/j.cbd.2009.07.001.

ANZECC \& ARMCANZ. 2000. Australian and New Zealand guidelines for fresh and marine water quality. Australian and New Zealand Environment and Conservation Council and 
473

474

475

476

477

478

479

480

481

482

483

484

485

486

487

488

489

490

491

492

493

494

495

496

497

498

499

500

Agriculture and Resource Management Council of Australia and New Zealand. Canberra, $A C T$, Australia.

ANZG. 2018. Australian and New Zealand Guidelines for fresh and marine water quality. Australian and New Zealand Governments and Australian state and territory governments, Canberra ACT, Australia. Available at http://www.waterquality.gov.au/anz-guidelines.

APVMA. 2003. The reconsideration of registrations of products containing diazinon and their labels. Part 1: Product cancellations. Review Report. Licensed from the Australian Pesticides and Veterinary Medicines Authority (APVMA) under a Creative Commons Attribution 3.0 Australia Licence. Canberra ACT, Australia.

APVMA. 2009. Review of the mammalian toxicology and metabolism/toxicokinetics of fipronil. Office of Chemical Safety \& Environmental Health Office of Health Protection of the Department of Health and Ageing. Canberra.

APVMA. 2012. Fipronil - Review Scope Document. Part 2: Environmental considerations. Licensed from the Australian Pesticides and Veterinary Medicines Authority (APVMA) under a Creative Commons Attribution 3.0 Australia Licence. Canberra ACT, Australia.

Babcock RC, and Heyward AJ. 1986. Larval development of certain gamete-spawning scleractinian corals. Coral Reefs 5:111-116.

Baird TD, and DeLorenzo ME. 2010. Descriptive and mechanistic toxicity of conazole fungicides using the model test alga Dunaliella tertiolecta (Chlorophyceae). Environmental Toxicology 25:213-220.

Bejarano AC, Chandler GT, Decho AW. 2005. Influence of natural dissolved organic matter (DOM) on acute and chronic toxicity of the pesticides chlorothalonil, chlorpyrifos and fipronil on the meiobenthic estuarine copeped Amphiascus tenuiremis. Journal of Experimental Marine Biology and Ecology 321:43-57.

Belanger S, Barron M, Craig P, Dyer S, Galay-Burgos M, Hamer M, Marshall S, Posthuma L, Raimondo S, and Whitehouse P. 2016. Future needs and recommendations in the development of Species Sensitivity Distributions: Estimating toxicity thresholds for 
501

502

503

504

505

506

507

508

509

510

511

512

513

514

515

516

517

518

519

520

521

522

523

524

525

526

527

528

aquatic ecological communites and assessing impacts of chemical exposures. Integrated Environmental Assessment and Management 13:664-674.

Bellas J. 2006. Comparative toxicity of alternative antifouling biocides on embryos and larvae of marine invertebrates. Science of the Total Environment 367:573-585.

Betancourt-Lozano M, Baird DJ, Sangha RS, and Gonzalez-Farias FA. 2006. Induction of morphological deformities and moulting alterations in Litopenaeus vannamei (Boone) juveniles exposed to the triazole-derivative fungicide Tilt. Archives of Environmental Contamination and Toxicology 51:69-78.

Bhuiyan SA, Croft BJ, and Tucker GR. 2014. Efficacy of the fungicide flutriafol for the control of pineapple sett rot of sugarcane in Australia. Australasian Plant Pathology 43:413-419.

Brodie JE, Lewis SE, Collier CJ, Wooldridge S, Bainbridge ZT, Waterhouse J, Rasheed MA, Honchin C, Holmes G, and Fabricius KE. 2017. Setting ecologically relevant targets for river pollutant loads to meet marine water quality requirements for the Great Barrier Reef, Australia: A preliminary methodology and analysis. Ocean \& Coastal Management 143:136-147.

Butcherine P, Kelaher BP, Taylor MD, Barkla BJ, and Benkendorff K. 2020. Impact of imidacloprid on the nutritional quality of adult black tiger shrimp (Penaeus monodon). Ecotoxicology and Environmental Safety 198:110682. doi: 10.1016/j.ecoenv.2020.110682.

Cantin NE, Negri AP, and Willis BL. 2007. Photoinhibition from chronic herbicide exposure reduces reproductive output of reef-building corals. Marine Ecology Progress Series 344:81-93.

Casida JE, and Quistad GB. 2004. Why insecticides are more toxic to insects than people: The unique toxicology of insects. Journal of Pesticide Science 29:81-86.

Chandler GT, Cary TL, Volz DC, Walse SS, Ferry JL, and Klosterhaus, SL. 2004. Fipronil effects on estuarine copepod (Amphiascus tenuiremis) development, fertility, and reproduction: a rapid life-cycle assay in 96-well microplate format. Environmental Toxicology and Chemistry 23(1):117-124. 
529

530

531

532

533

534

535

536

537

538

539

540

541

542

543

544

545

546

547

548

549

550

551

552

553

554

555

556

Chapman JA, Kirkness EF, Simakov O, Hampson SE, Mitros T, Weinmaier T, Rattei T, Balasubramanian PG, Borman J, Busam D, Disbennett K, Pfannkoch C, Sumin N, Sutton GG, Viswanathan LD, Walenz B, Goodstein DM, Hellsten U, Kawashima T, Prochnik SE, Putnam NH, Shu S, Blumberg B, Dana CE, Gee L, Kibler DF, Law L, Lindgens D, Martinez DE, Peng J, Wigge PA, Bertulat B, Guder C, Nakamura Y, Ozbek S, Watanabe H, Khalturin K, Hemmrich G, Franke A, Augustin R, Fraune S, Hayakawa E, Hayakawa S, Hirose M, Hwang JS, Ikeo K, Nishimiya-Fujisawa C, Ogura A, Takahashi T, Steinmetz PRH, Zhang X, Aufschnaiter R, Eder M-K, Gorny A-K, Salvenmoser W, Heimberg AM, Wheeler BM, Peterson KJ, Böttger A, Tischler P, Wolf A, Gojobori T, Remington KA, Strausberg RL, Venter JC, Technau U, Hobmayer B, Bosch TCG, Holstein TW, Fujisawa T, Bode HR, David CN, Rokhsar DS, and Steele RE. 2010. The dynamic genome of Hydra. Nature 464:592596. doi: $10.1038 /$ nature 08830

Cima F, Bragain M, and Ballarin L. 2008. Toxic effects of new antifouling compounds on tunicate haemocytes I. Sea-Nine $211^{\text {TM }}$ and chlorothalonil. Aquatic Toxicology 86:299-312.

Cox C. 1997. Fungicide Factsheet: Chlorothalonil. Journal of Pesticide Reform 17:14-20.

Cox C. 2000. Diazinon: Toxicology. Journal of Pesticide Reform 20:15-20.

Davis AM, Lewis SE, Bainbridge ZT, Brodie JE, and Shannon E. 2008. Pesticide residues in waterways of the Lower Burdekin region: Challenges in ecotoxicological interpretation of monitoring data. Australasian Journal of Ecotoxicology 14:89-108.

Davis AM, Lewis SE, Brodie JE, and Benson A. 2014. The potential benefits of herbicide regulation: A cautionary note for the Great Barrier Reef catchment area. Science of the Total Environment 490:81-92.

DeLorenzo ME, and Serrano, L. 2003. Individual and mixture toxicity of three pesticides; atrazine, chlorpyrifos and chlorothalonil to the marine phytoplankton species Dunaliella tertiolecta. Journal of Environmental Science and Health, Part B 38:529-538.

Devlin M, Lewis S, Davis A, Smith R, Negri A, Thompson A, and Poggio M. 2015. Advancing our understanding of the source, management, transport and impacts of pesticides on the Great Barrier Reef. A report for the Queensland Department of Environment and 
557

558

559

560

561

562

563

564

565

566

567

568

569

570

571

572

573

574

575

576

577

578

579

580

581

582

583

584

585

Heritage Protection: Tropical Water \& Aquatic Ecosystem Research (TropWATER) Publication, James Cook University, Cairns, 134 pp.

Di Toro DM, McGrath JA, and Hansen DJ. 2000. Technical basis for narcotic chemicals and polycyclic aromatic hydrocarbon criteria. I. Water and tissue. Environmental Toxicology and Chemistry 19:1951-1970.

Donner SD, and Potere D. 2007. The Inequity of the Global Threat to Coral Reefs. BioScience 57:214-215. doi: 10.1641/b570302

eAtlas. 2020. Environmental research, maps and data for tropical Australia. Available at https://eatlas.org.au/data/uuid/da9fc37d-e74b-477d-8cd5-79178cda968c.

Eisler R. 1998. Copper hazards to fish, wildlife and invertebrates: a synoptic review. Contaminant Hazard Reviews. Laurel, MD. p 103.

Environment Canada. 2005. Toxicity testing using imidacloprid: inland silverside test report. Prepared by Stantec Inc. for the National Guidelines and Standards Office, Environment Canada. Ottawa.

Ewere EE, Reichelt-Brushett A, and Benkendorff K. 2019. Imidacloprid and formulated product impacts the fatty acids and enzymatic activities in tissues of Sydney rock oysters, Saccostrea glomerata. Marine Environmental Research 151:104765. doi: 10.1016/j.marenvres.2019.104765

Faltine-Gonzalez DZ, and Layden MJ. 2019. Characterization of nAChRs in Nematostella vectensis supports neuronal and non-neuronal roles in the cnidarian-bilaterian common ancestor. EvoDevo 10:27. doi: 10.1186/s13227-019-0136-3

Fisher R, Ricardo GF, and Fox DR. 2019. jagsNEC: A Bayesian No Effect Concentration (NEC) package. R package version 1. https://github.com/AIMS/NEC-estimation. R package version 1.0.

Fox DR. 2010. A Bayesian approach for determining the no effect concentration and hazardous concentration in ecotoxicology. Ecotoxicology and Environmental Safety 73:123-131. doi: 10.1016/j.ecoenv.2009.09.012.

Furnas M. 2003. Catchments and corals: terrestrial runoff to the Great Barrier Reef: Australian Institute of Marine Science, Towsnville, QLD. 
586 Gallen C, Thai P, Paxman C, Prasad P, Elisei G, Reeks T, Eaglesham G, Yeh R, Tracey D, Grant S, 587 and Mueller JF. 2019. Marine Monitoring Program: Annual Report for inshore pesticide

588

589

590

591

592

593

594

595

596

597

598

599

600

601

602

603

604

605

606

607

608

609

610

611

612

613

614 monitoring 2017-18. Report for the Great Barrier Reef Marine Park Authority, Great Barrier Reef Marine Park Authority. Townsville, 118 pp.

Garber K, and Steeger T. 2008. Problem formulation for the environmental fate and ecological risk, endangered species and drinking water assessments in support of the registration review of diazinon. US Environmental Protection Agency, Office of Prevention, Pesticides, and Toxic Substances Office of Pesticide Programs, Washington, DC.

Garland SM, Davies NW, and Menary RC. 2004. The dissipation of tebuconazole and propiconazole in Boronia (Boronia megastigma Nees). Journal of Agicultural and Food Chemistry 52(20):6200-6204.

Gilbert M, and Brodie J. 2001. Population and major land use in the Great Barrier Reef catchment area: spatial and temporal trends. Townsville: Great Barrier Reef Marine Park Authority. p 79.

Gissi F, Stauber J, Reichelt-Brushett A, Harrison PL, and Jolley DF. 2017. Inhibition in fertilisation of coral gametes following exposure to nickel and copper. Ecotoxicology and Environmental Safety 145:32-41.

Gunasekara AS, Truong T, Goh KS, Spurlock F, and Tjeerema RS. 2007. Environmental fate and toxicology of fipronil. Journal of Pesticide Science 32:189-199. doi: 10.1584/jpestics.R0702.

Harrison PL, and Wallace CC. 1990. Reproduction, dispersal and recruitment of scleractinian corals. In: Dubinsky Z, ed. Coral Reefs (Ecosystems of the World; 25). New York: Elsevier Science Publishing Company, 133-207.

Heery EC, Hoeksema BW, Browne NK, Reimer JD, Ang PO, Huang D, Friess DA, Chou LM, Loke LHL, Saksena-Taylor P, Alsagoff N, Yeemin T, Sutthacheep M, Vo ST, Bos AR, Gumanao GS, Syed Hussein MA, Waheed Z, Lane DJW, Johan O, Kunzmann A, Jompa J, Suharsono, Taira D, Bauman AG, and Todd PA. 2018. Urban coral reefs: Degradation and resilience of hard coral assemblages in coastal cities of East and Southeast Asia. Marine Pollution Bulletin 135:654-681. doi: 10.1016/j.marpolbul.2018.07.041 
615 Heyward AJ, and Negri AP. 1999. Natural inducers for coral larval metamorphosis. Coral Reefs $616 \quad 18: 273-279$.

617 Holligan E, Cook S, Poggio M, and Rattray D. 2017. Economic assessment of best management 618 practices for banana growing, Report to the Department of Environment and Heritage

619

620

621

622

623

624

625

626

627

628

629

630

631

632

633

634

635

636

637

638

639

640

641 Protection through funding from the Reef Water Quality Science Program, RP140B Technical Report. Department of Agriculture and Fisheries (DAF) and the Department of Natural Resources and Mines (DNRM), Queensland.

Horiuchi Y, Kimura R, Kato N, Fujii T, Seki M, Endo T, Kato T, and Kawashima K. 2003. Evolutional study on acetycholine expression. Life Sciences 72:1745-1756.

Hughes TP, Anderson KD, Connolly SR, Heron SF, Kerry JT, Lough JM, Baird AH, Baum JK, Berumen ML, Bridge TC, Claar DC, Eakin CM, Gilmour JP, Graham NAJ, Harrison H, Hobbs J-PA, Hoey AS, Hoogenboom M, Lowe RJ, McCulloch MT, Pandolfi JM, Pratchett M, Schoepf V, Torda G, and Wilson SK. 2018. Spatial and temporal patterns of mass bleaching of corals in the Anthropocene. Science 359:80-83. doi: 10.1126/science.aan8048.

Iyer P, and Makris S. 2010. Developmental and Reproductive Toxicology of Pesticides. In: Krieger R, ed. Hayes Handbook of Pesticide Toxicology (Third Edition): Elsevier. Jameson SC, Stevens K, Bennett RC, and Cardoza NJT. 2019. Chapter 32 - Nicaragua: Pacific Coast. In: Sheppard C, ed. World Seas: an Environmental Evaluation (Second Edition): Academic Press, 743-757.

Jones RJ. 2005. The ecotoxicological effects of Photosystem II herbicides on corals. Marine Pollution Bulletin 51:495-506.

Jones RJ, and Kerswell AP. 2003. Phytotoxicity of photosystem II (PSII) herbicides to coral. Marine Ecology Progress Series 261:149-159.

Kass-Simon G, and Pierobon P. 2007. Cnidarian chemical neurotransmission, an updated review. Comparative Biochemistry and Physiology, Part A Molecular \& Integrative Physiology 146:9-25. 
642 Kast-Hutcheson K, Rider CV, and LeBlanc GA. 2001. The fungicide propiconazole interferes with 643 embryonic development of the crustacean Daphnia magna. Environmental Toxicology $644 \quad$ and Chemistry 20:502-509. doi: 10.1002/etc.5620200308.

645 Key PB, Chung KW, Opatkiewicz AD, Wirth EF, and Fulton MH. 2003. Toxicity of the insecticides 646 fipronil and endosulfan to selected life stages of the grass shrimp (Palaemonetes pugio). Bulletin of Environmental Contamination and Toxicology 70:533-540.

Key P, Chung K, Siewicki T, and Fulton M. 2007. Toxicity of three pesticides individually and in 649 mixture to larval grass shrimp (Palaemonetes pugio). Ecotoxicology and Environmental Safety 68:272-277.

King J, Alexander F, and Brodie J. 2013. Regulation of pesticides in Australia: the Great Barrier Reef as a case study for evaluating effectiveness. Agriculture, Ecosystems and Environment 180:54-67.

King OC, Smith RA, Mann RM, and Warne MSJ. 2017a. Proposed aquatic ecosystem protection guideline values for pesticides commonly used in the Great Barrier Reef catchment area: Part 1 (amended) - 2,4-D, Ametryn, Diuron, Glyphosate, Hexazinone, Imazapic, Imidacloprid, Isoxaflutole, Metolachlor, Metribuzin, Metsulfuron-methyl, Simazine,

King OC, Smith RA, Warne MSJ, Frangos JS, and Mann RM. 2017b. Proposed aquatic ecosystem protection guideline values for pesticides commonly used in the Great Barrier Reef Merwe J, Warne MSJ, and Williams M. 2015. Identification, impacts, and prioritisation of emerging contaminants present in the GBR and Torres Strait marine environments. 
670

671

672

673

674

675

676

677

678

679

680

681

682

683

684

685

686

687

688

689

690

691

692

693

694

695

696

697

Report to the National Environmental Science Programme: Reef and Rainforest Research Centre Limited, Cairns. p 138 pp.

Laurance WF, Sayer J, and Cassman KG. 2014. Agricultural expansion and its impacts on tropical nature. Trends in Ecology \& Evolution 29:107-116. doi: 10.1016/j.tree.2013.12.001.

Lee YH, Park JC, Hwang U-K, Lee J-S, Han J. 2018. Adverse effects of the insecticides chlordecone and fipronil on population growth and expression of the entire cytochrome P450 (CYP) genes in the freshwater rotifer Brachionus calyciflorus and the marine rotifer Brachionus plicatilis. Aquatic Toxicology 202:181-187.

Lewis SE, Brodie JE, Bainbridge ZT, Rohde KW, Davis AM, Masters BL, Maughan M, Devlin MJ, Mueller JF, and Schaffelke B. 2009. Herbicides: A new threat to the Great Barrier Reef. Environmental Pollution 157:2470-2484.

Li Z-H, Zlabek V, Grabic R, Li P, and Randak T. 2010. Modulation of glutathione-related antioxidant defense system of fish chronically treated by the fungicide propiconazole. Comparative Biochemistry and Physiology, Part C 152:392-398.

Markey KL, Baird AH, Humphrey C, and Negri AP. 2007. Insecticides and a fungicide affect multiple coral life stages. Marine Ecology Progress Series 330:127-137.

Mercurio P. 2016. Herbicide persistence and toxicity in the tropical marine environment. PhD Thesis. University of Queensland. 148 pp. doi: 10.14264/uql.2016.722.

Mercurio P, Eaglesham G, Parks S, Kenway M, Beltran V, Flores F, Mueller JF, and Negri AP. 2018. Contribution of transformation products towards the total herbicide toxicity to tropical marine organisms. Scientific Reports 8:4808. doi: 10.1038/s41598-018-23153-4

Mercurio P, Mueller JF, Eaglesham G, Flores F, and Negri AP. 2015. Herbicide persistence in seawater simulation experiments. PLoS One 10:e0136391.

Moeller M, Nietzer S, and Schupp PJ. 2018. Neuroactive compounds induce larval settlement in the scleractinian coral Leptastrea purpurea. Scientific Reports 9. doi: 10.1038/s41598019-38794-2.

Morgan MB, and Snell TW. 2002. Characterizing stress gene expression in reef-building corals exposed to the mosquitoside dibrom. Marine Pollution Bulletin 44:1206-1218.

PeerJ reviewing PDF | (2020:05:48551:2:0:NEW 1 Jul 2020) 
698 Negri A, Vollhardt C, Humphrey C, Heyward A, Jones R, Eaglesham G, and Fabricius K. 2005.

699

700

701

702

703

704

705

706

707

708

709

710

711

712

713

714

715

716

717

718

719

720

721

722

723

724

725

Effects of the herbicide diuron on the early life history stages of coral. Marine Pollution Bulletin 51:370-383.

Negri AP, Brinkman DL, Flores F, Botté ES, Jones RJ, and Webster NS. 2016. Acute ecotoxicology of natural oil and gas condensate to coral reef larvae. Scientific Reports 6:21153. 10.1038/srep21153. https://www.nature.com/articles/srep21153\#supplementaryinformation.

Negri AP, Flores F, Röthig T, and Uthicke S. 2011a. Herbicides increase the vulnerability of corals to rising sea surface temperature. Limnology and Oceanography 56:471-485. doi: 10.4319/lo.2011.56.2.0471.

Negri AP, Harford AJ, Parry DL, and van Dam RA. 2011b. Effects of alumina refinery wastewater and signature metal constituents at the upper thermal tolerance of: 2 . The early life stages of the coral Acropora tenuis. Marine Pollution Bulletin 62:474-482.

Negri AP, and Heyward AJ. 2000. Inhibition of fertilization and larval metamorphosis of the coral Acropora millepora (Ehrenberg, 1834) by petroleum products. Marine Pollution Bulletin 41:420-427.

Negri AP, and Heyward AJ. 2001. Inhibition of coral fertilisation and larval metamorphosis by tributyltin and copper. Marine Environmental Research 51:17-27.

Negri AP, and Hoogenboom MO. 2011. Water contamination reduces the tolerance of coral larvae to thermal stress. PLoS One. doi: 10.1371/journal.pone.0019703.

Negri AP, Smith RA, King O, Frangos J, Warne MSJ, and Uthicke S. 2020. Adjusting tropical marine water quality guideline values for elevated ocean temperatures. Environmental Science \& Technology 54:1102-1110.

Negri AP, Soo RM, Flores F, and Webster NS. 2009. Bacillus insecticides are not acutely harmful to corals and sponges. Marine Ecology Progress Series 381:157-165.

Nordborg M, Flores F, L. Brinkman D, Agustí S, and Negri A. 2018. Phototoxic effects of two common marine fuels on the settlement success of the coral Acropora tenuis. Scientific Reports 8. doi: 10.1038/s41598-018-26972-7. 
726 O'Brien D, Lewis S, Davis A, Gallen C, Smith R, Turner R, Warne MSJ, Turner S, Caswell S, Mueller

727 JF, and Brodie J. 2016. Spatial and temporal variability in pesticide exposure

728 downstream of a heavily irrigated cropping area: Application of different monitoring

729 techniques. Journal of Agricultural and Food Chemistry 64:3975-3989.

730 O'Brien D, Lewis S, Gallen C, O'Brien J, Thompson K, Eaglesham G, and Mueller JF. 2014. Barron

731 River pesticide monitoring and Cairns WWTP WQ assessment. Report No 14/40, Centre

732 for Tropical Water \& Aquatic Ecosystem Research (TropWATER) Publication, James Cook

$733 \quad$ University, Cairns, 48 pp.

734 O'Brien D, Nash M, Di Bella L, and Brodie J. 2015. Reef Plan Herbert Water Quality Program

735 (HWQMP) Final report for monitoring undertaken between 2011 and 2014. Centre for

736 Tropical Water and Aquatic Ecosystem Research Publication. James Cook University,

737 Townsville, Australia pp. 167. p Availabe from:

738 https://research.jcu.edu.au/tropwater/publications/1518ReefplanHerbertwaterquality

739 monitoringprogram.pdf.

740 Ochoa-Acuña HG, Bialkowski W, Yale G, and Hahn L. 2009. Toxicity of soybean rust fungicides to

741 freshwater algae and Daphnia magna. Ecotoxicology 18:440-446.

742 Osterberg JS, Darnell KM, Blickley TM, Romano JA, and Rittschof D. 2012. Acute toxicity and

743 sub-lethal effects of common pesticides in post-larval and juvenile blue crabs,

744 Callinectes sapidus. Journal of Experimental Marine Biology and Ecology 424-425:5-14.

745 Owen R, Knap A, Toaspern M, and Carbery K. 2002. Inhibition of coral photosynthesis by the

$746 \quad$ antifouling herbicide Irgarol 1051. Marine Pollution Bulletin 44:623-632.

747 Pak D, You MP, Lanoiselet V, and Barbetti MJ. 2017. Azoxystrobin and propiconazole offer

748 significant potential for rice blast (Pyricularia oryzae) management in Australia.

749 European Journal of Plant Pathology 148:247-259.

750 Palmer CV, and Traylor-Knowles NG. 2018. Cnidaria: Anthozoans in the hot seat. In: Cooper EL,

751 ed. Advances in Comparative Immunology. New York City, NY, USA: Springer

752 International Publishing, 1048.

753 Pesando D, Huitorel P, Dolcini V, Angelini C, Guidetti P, and Falugi C. 2003. Biological targets of 754 neurotoxic pesticides analysed by alteration of developmental events in the 
755

756

757

758

759

760

761

762

763

764

765

766

767

768

769

770

771

772

773

774

775

776

777

778

779

780

781

782

783

Mediterranean sea urchin, Paracentrotus lividus. Marine Environmental Research 55:3957. doi: 10.1016/S0141-1136(02)00215-5.

Plumlee KH. 2004. Chapter 21 - Insecticides and Molluscides. Clinical Veterinary Toxicology:177192.

R Core Team. 2017. R: A language and environment for statistical computing. R Foundation for Statistical Computing, Vienna, Austria. URL https://www.R-project.org/.

Raman P. 2014. Chlorothalonil. Encyclopedia of toxicology (Third edition):919-922.

Reichelt-Brushett AJ, and Harrison PL. 2000. The effect of copper on the settlement success of larvae from the scleractinian coral Acropora tenuis. Marine Pollution Bulletin 41:385391.

Reichelt-Brushett AJ, and Harrison PL. 2004. Development of a sublethal test to determine the effects of copper and lead on scleractinian coral larvae. Archives of Environmental Contamination and Toxicology 47:40-55. doi: 10.1007/s00244-004-3080-7.

Richmond RH. 1987. Energetics, competency, and long-distance dispersal of planula larvae of the coral Pocillopora damicornis. Marine Biology 93:527-533.

Ross C, Olsen K, Henry M, and Pierce R. 2015. Mosquito control pesticides and sea surface temperatures have differential effects on the survival and oxidative stress response of coral larvae. Ecotoxicology 24:540-552.

RWQIP. 2018. Reef 2050 Water Quality Improvement Plan 2017-2022. Australian and Queensland Government. https://www.reefplan.qld.gov.au/_data/assets/pdf_file/0017/46115/reef-2050-waterquality-improvement-plan-2017-22.pdf.

Salvat BM. 1992. Coral reefs - a challenging ecosystem for human societies. Global Environmental Change 2:12-18.

Sammarco PW. 1982. Polyp bail-out: an escape response to environmental stress and new means of reproduction in corals. Marine Ecology Progress Series 10:57-65.

Sany SBT, Tajfard M, Rezayi M, Rahman MA, and Hashim R. 2019. Chapter 20 - The West Coast of Peninsular Malaysia. In: Sheppard C, ed. World Seas: an Environmental Evaluation (Second Edition): Academic Press, 437-458. 
784 Sinclair CJ, and Boxall ABA. 2003. Assessing the ecotoxicity of pesticide transformation 785 products. Environmental Science \& Technology 37:4617-4625. doi: 10.1021/es030038m.

786

787

788

789

790

791

792

793

794

795

796

797

798

799

800

801

802

803

804

805

806

807

808

809

810

811

812

Song MY, Stark JD, and Brown JJ. 1997. Comparative toxicity of four insecticides, including imidacloprid and tebufenozide, to four aquatic arthropods. Environmental Toxicology and Chemistry 16:2494-2500.

Stenersen J. 2004. Chemical pesticides: mode of action and toxicology: CRC Press LLC, Boca Raton, FL, USA.

Stoughton SJ. 2006. Toxicity of imidacloprid to two aquatic invertebrates, Chironomus tentans and Hyalella azteca, under different exposure conditions. M.Sc. Thesis. University of Saskatchewan, Saskatoon.

Sunderam RIM, Warne MSJ, Chapman JC, Pablo F, Hawkins J, Rose RM, and Patra RW. 2000. The ANZECC and ARMCANZ water quality guideline database for toxicants.

Talesa V, Principato GB, Mangiabene C, Giovannini E, Norton SJ, and Rosi G. 1992. Cholinesterase in the Cnidarians Velella velella (Hydrozoa: Syphonophora) and Actinia equina (Anthozoa: Actinaria): A comparative study. Journal of Experimental Zoology 263:367-373.

Te FT. 1998. Preliminary investigations into the effects of Dursban registered insecticide on Pocillopora damicornis (Scleractinia: Cnidaria) Journal of Marine Environmental Engineering 4:189-199.

Thomas MC, Flores F, Kaserzon S, Fisher R, and Negri AP. 2020. Toxicity of ten herbicides to the tropical marine microalgae Rhodomonas salina. Scientific Reports 10:7612. doi: 10.1038/s41598-020-64116-y.

Thorburn PJ, Wilkinson SN, and Silburn DM. 2013. Water quality in agricultural lands draining to the Great Barrier Reef: A review of causes, management and priorities. Agriculture, Ecosystems \& Environment 180:4-20.

Tillman RW, Siegel MR, and Long JW. 1973. Mechanism of action and fate of the fungicide chlorothalonil (2,4,5,6-tetrachloroisophthalonitrile) in biological systems: I. Reactions with cells and subcellular components of Saccharomyces pastorianus. Pesticide Biochemistry and Physiology 3:160-167. doi: 10.1016/0048-3575(73)90100-4 
813 Tomizawa M, and Casida JE. 2005. Neonicotinoid insecticide toxicology: Mechanisms of

814 selective action. Annual Review of Pharmacology and Toxicology 45:247-268. doi:

815 10.1146/annurev.pharmtox.45.120403.095930

Traas TP, Van de Meent D, Posthuma L, Hamers T, Kater BJ, de Zwart D, and Aldenberg T. 2002. The potentially affected fraction as a measure of ecological risk. In Species Sensitivity Distributions in Ecotoxicology; Posthuma, L; Suter, GW II, Traas TP (Eds) Boca Raton, FL, USA: CRC Press: Lewis, pp 315-344.

USEPA. 2006. Reregistration eligibility decision (RED) for propiconazole. In: Edwards D, editor: USEPA, Dept of Prevention, Pesticides and Toxic Substances.

USEPA. 2015. Office of Pesticide Programs Pesticide Ecotoxity Database. The Ecological Fate and

Ward GS. 1990. NTN 33893 Technical: acute toxicity to the mysid, Mysidopsis bahia, under flow-through test conditions. Toxicon Environmental Sciences, Jupiter, Florida (performing laboratory). Mobay Corporation, Kansas City, Missouri (submitting laboratory). 46 pp. Mobay Report No. 100355.

Warne MSJ, Batley GE, van Dam RA, Chapman JC, Fox DR, Hickey CW, and Stauber JL. 2018a. Revised Method for Deriving Australian and New Zealand Water Qulaity Guideline Values for Toxicants - update of 2015 version. Prepared for the revision of the Australian and New Zealand Guidelines for Fresh and Marine Water Quality. Australian and New Zealand Governments and Australian state and territory governments, Canberra, 48 pp. 
842 Warne MSJ, King O, and Smith RA. 2018b. Ecotoxicity thresholds for ametryn, diuron, 843 hexazinone and simazine in fresh and marine waters. Environmental Science and $844 \quad$ Pollution Research 25:3151-3169.

845 Warne MSJ, Smith RA, and Turner RDR. 2020. Analysis of pesticide mixtures discharged to the 846 lagoon of the Great Barrier Reef, Australia. Environmental Pollution. doi:

$847 \quad$ 10.1016/j.envpol.2020.114088.

848 Watanabe T, Yuyama I, and Yasumura S. 2006. Toxicological effects of biocides on symbiotic 849 and aposymbiotic juveniles of the hermatypic coral Acropora tenuis. Journal of $850 \quad$ Experimental Marine Biology and Ecology 339:177-188.

851 Waterhouse J, Brodie J, Lewis S, and Mitchell A. 2012. Quantifying the sources of pollutants in 852 the Great Barrier Reef catchments and the relative risk to reef ecosystems. Marine Pollution Bulletin 65:394-406.

Wecker P, Lecellier G, Guibert I, Zhou Y, Bonnard I, and Berteaux-Lecellier V. 2018. Exposure to 855 the enivronmentally-persistent insecticide chlordecone induces detoxification genes and causes polyp bail-out in the coral P. damicornis. Chemosphere 195:190-200. 


\section{Figure 1}

Photographs after $48 \mathrm{~h}$ exposure

(A) planula larvae in control treatment; (B) attached post-metamorphosis polyp in control treatment; (C) larvae exposed to $228 \mu \mathrm{g} \mathrm{L}^{-1}$ propiconazole showing slightly abnormal shape but still moving and (D) larvae exposed to $56.3 \mu \mathrm{g} \mathrm{L}^{-1}$ chlorothalonil showing rupturing of cells. 


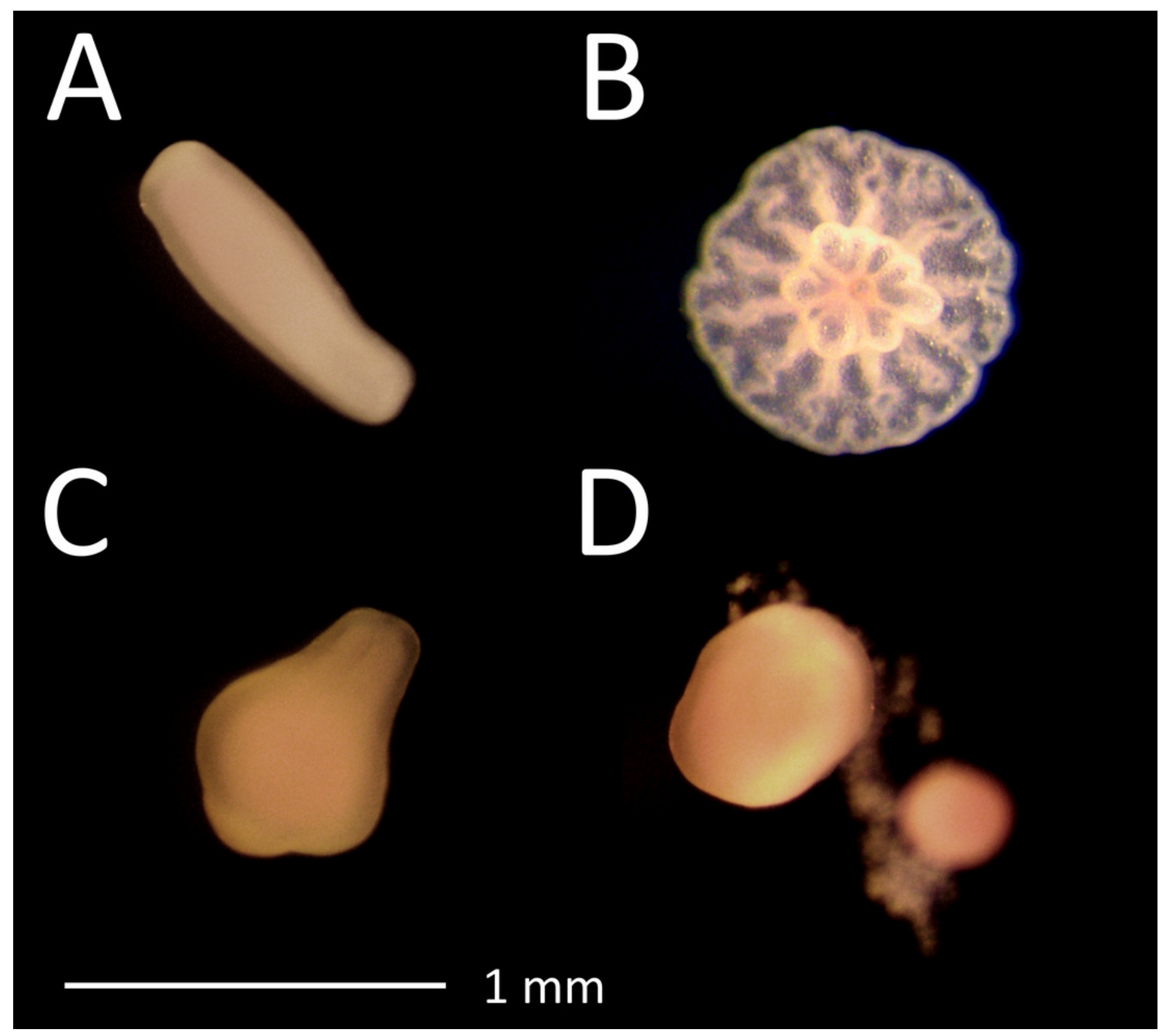




\section{Figure 2}

Concentration-response relationships

Concentration-response relationships for the toxicity of five pesticides and the reference toxicant copper to $A$. tenuis coral larval metamorphosis. Beta segmented-regression model fits (binomial segmented-regression model fits for imidacloprid and propiconazole) on the proportional decline of coral larval metamorphosis relative to the solvent control treatment (solid black line) and $95 \%$ credible intervals (dashed black line) to derive no effect concentrations (red line) and $95 \%$ credible intervals (dashed red line) of A) diazinon; B) fipronil; C) imidacloprid; D) chlorothalonil; E) propiconazole; F) copper. 

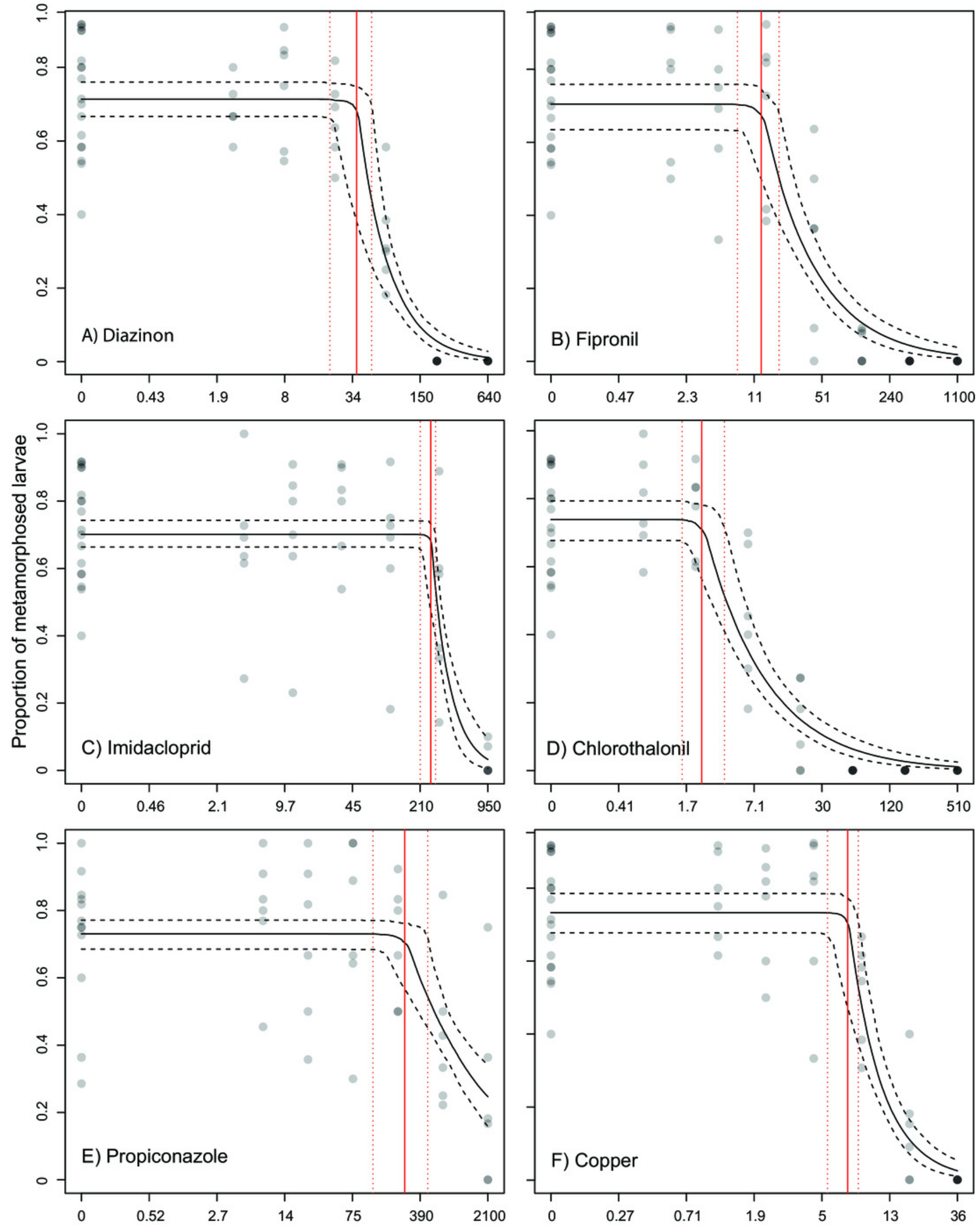

Herbicide concentration $\left(\mu \mathrm{g} \mathrm{L}^{-1}\right)$ 


\section{Table 1 (on next page)}

Pesticides used in present study

Pesticides used in this study, their class, mode of action and target pests in Australia. Water solubilities and $\log \mathrm{K}_{\mathrm{ow}}$ values from PubChem Database (National Center for Biotechnology Information, https://pubchem.ncbi.nIm.nih.gov/compound/ (accessed on Apr. 20, 2020)). 


\begin{tabular}{|c|c|c|c|c|}
\hline Pesticide & $\begin{array}{l}\text { Type and class of } \\
\text { pesticide }\end{array}$ & Mode of action & Target pests & $\begin{array}{l}\text { Water solubility in } \\
\mathrm{mg} \mathrm{L}^{-1}\left(\log \mathrm{K}_{\text {ow }} \text { at } 25\right. \\
\left.{ }^{\circ} \mathrm{C}\right)\end{array}$ \\
\hline Diazinon & $\begin{array}{l}\text { Insecticide - } \\
\text { Organophosphate }\end{array}$ & $\begin{array}{l}\text { Inhibits acetylcholinesterase from breaking down } \\
\text { acetylcholine, which leads to continual nerve } \\
\text { stimulation (Cox 2000; Garber \& Steeger 2008) }\end{array}$ & $\begin{array}{l}\text { Lice, buffalo fly, mange; } \\
\text { ectoparasites (APVMA 2003; } \\
\text { ARMCANZ 2000) }\end{array}$ & $40(3.81)$ \\
\hline Fipronil & $\begin{array}{l}\text { Insecticide - } \\
\text { Phenylpyrazole }\end{array}$ & $\begin{array}{l}\text { Blocks the neurotransmitter gamma- } \\
\text { aminobutyric acid (GABA) and glutamate-gated } \\
\text { chloride channels, causing hyperexcitation of the } \\
\text { central nervous system (Anadon \& Gupta 2012; } \\
\text { APVMA 2009; Gunasekara et al. 2007; Stenersen } \\
\text { 2004) }\end{array}$ & $\begin{array}{l}\text { Locusts, grasshoppers (APVMA } \\
\text { 2012) }\end{array}$ & $2(4.0)$ \\
\hline Imidacloprid & $\begin{array}{l}\text { Insecticide - } \\
\text { Neonicotinoid }\end{array}$ & $\begin{array}{l}\text { Irreversibly binds to postsynaptic nicotinic } \\
\text { acetylcholine receptors disrupting normal neural } \\
\text { transmission (Abbink 1991; Plumlee 2004; } \\
\text { Stenersen 2004) }\end{array}$ & $\begin{array}{l}\text { Canegrub (Davis et al. 2008; Devlin } \\
\text { et al. 2015; King et al. 2017a) }\end{array}$ & $610(0.57)$ \\
\hline Chlorothalonil & $\begin{array}{l}\text { Fungicide - } \\
\text { Organochlorine }\end{array}$ & $\begin{array}{l}\text { Chemically reduces the antioxidant glutathione; } \\
\text { enzymes that are dependent on glutathione, } \\
\text { including enzymes important in cellular function, } \\
\text { become non-functional (Cox 1997; Raman 2014) }\end{array}$ & $\begin{array}{l}\text { Fungal diseases of cereals, fruits } \\
\text { and vegetables (e.g. wheat, stone } \\
\text { fruit, strawberries, potatoes) and } \\
\text { other crops (peanuts, tobacco) } \\
\text { (King et al. 2017b) }\end{array}$ & $0.81(3.05)$ \\
\hline Propiconazole & $\begin{array}{l}\text { Fungicide - } \\
\text { Triazole }\end{array}$ & $\begin{array}{l}\text { Inhibits ergosterol biosynthesis critical to the } \\
\text { formation of cell walls of fungi, thus inhibiting } \\
\text { fungal growth (USEPA 2006) }\end{array}$ & $\begin{array}{l}\text { Rice blast fungus, pineapple sett } \\
\text { rot, rust fungi, fungal diseases of } \\
\text { bananas, oats, peanuts, perennial } \\
\text { ryegrass, stone fruit, sugar cane, } \\
\text { wheat (Bhuiyan et al. 2014; } \\
\text { Garland et al. 2004; Pak et al. } \\
\text { 2017) }\end{array}$ & $100(3.72)$ \\
\hline
\end{tabular}




\section{Table 2 (on next page)}

Toxicity estimates

Modelled toxicity estimates for the inhibition of coral larval metamorphosis by diazinon, fipronil, imidacloprid, chlorothalonil, propiconazole and copper to Acropora tenuis. No effect concentrations (NECs) and effect concentrations $\left(\mathrm{EC}_{10}\right.$ and $\left.\mathrm{EC}_{50}\right)$ were calculated from concentration-response curves (see Fig. 1). Meta. = mean larval metamorphosis (\%) of larvae in uncontaminated treatments $( \pm \mathrm{SE})$. All concentrations are in $\mu \mathrm{g} \mathrm{\textrm {L } ^ { - 1 }}$ (95\% confidence intervals). 


\begin{tabular}{lllll}
\hline & NEC & $\mathrm{EC}_{10}$ & $\mathrm{EC}_{50}$ & $\begin{array}{l}\text { Meta. }(\% \pm \mathrm{SE}) \text { in } \\
\text { controls }\end{array}$ \\
\hline Diazinon & $38.0(20.4-51.3)$ & $40.8(22.4-53.8)$ & $54.7(52.3-57.0)$ & $72.6 \pm 3.7$ \\
Fipronil & $12.3(7.1-19.1)$ & $13.9(8.5-21.1)$ & $29.1(20.2-41.6)$ & $72.6 \pm 3.7$ \\
Imidacloprid & $263(200-295)$ & $273(211-306)$ & $347(306-417)$ & $72.6 \pm 3.7$ \\
Chlorothalonil & $2.42(1.63-3.89)$ & $2.76(1.90-4.42)$ & $5.95(4.40-8.82)$ & $72.6 \pm 3.7$ \\
Propiconazole & $269(123-468)$ & $330(171-537)$ & $1008(704-1689)$ & $72.2 \pm 6.1$ \\
Copper & $7.41(5.75-8.45)$ & $7.79(6.13-8.82)$ & $10.2(8.6-11.5)$ & $72.6 \pm 3.7$ \\
\hline
\end{tabular}

1 


\section{Table 3 (on next page)}

Summary of single toxicity studies

Summary of a selection of single toxicity studies (estuarine and marine) using diazinon, fipronil, imidacloprid, chlorothalonil and propiconazole. Adapted from King et al. (2017a, 2017b). NEC - no effect concentration; LOEC - lowest observed effect concentration; NOEC no observed effect concentration; chr. est. NOEC - chronic estimated no observed effect concentration; NOEL - no observable effect level. 


\begin{tabular}{|c|c|c|c|c|c|c|}
\hline Phylum & Species & Life stage & $\begin{array}{l}\text { Test } \\
\text { duration } \\
\text { (in days) }\end{array}$ & Test endpoint(s) & $\begin{array}{l}\text { Effects concentration } \\
\left(\mu \mathrm{g} \mathrm{L}^{-1}\right)\end{array}$ & Reference \\
\hline \multicolumn{7}{|l|}{ Diazinon } \\
\hline Cnidaria & Acropora tenuis & Larvae & 2 & Metamorphosis & 38.0 (NEC) & Present study \\
\hline Arthropoda & Mysidopsis bahia & Not stated & 4 & Mortality & $6\left(\mathrm{LC}_{50}\right)$ & Sunderam et al. (2000) \\
\hline Arthropoda & Penaeus duorarum & Embryo & 4 & Mortality & $21\left(\mathrm{LC}_{50}\right)$ & Sunderam et al. (2000) \\
\hline Echinodermata & Paracentrotus lividus & Gamete & 0.125 & Fertilisation & 30400 (LOEC) & Pesando et al. (2003) \\
\hline Echinodermata & Paracentrotus lividus & Larvae & 1 & AChE inhibition & $30($ LOEC) & Pesando et al. (2003) \\
\hline \multicolumn{7}{|l|}{ Fipronil } \\
\hline Cnidaria & Acropora tenuis & Larvae & 2 & Metamorphosis & 12.3 (NEC) & Present study \\
\hline Arthropoda & Palaemonetes pugio & Embryo & 4 & Mortality & 32.0 (LOEC) & Key et al. (2003) \\
\hline Arthropoda & Palaemonetes pugio & Larvae & 4 & Mortality & 0.50 (LOEC) & Key et al. (2003) \\
\hline Arthropoda & Palaemonetes pugio & Larvae & 4 & Mortality & $0.68\left(L_{50}\right)$ & Key et al. (2007) \\
\hline Arthropoda & Palaemonetes pugio & Adult & 4 & Mortality & 0.13 (LOEC) & Key et al. (2003) \\
\hline Arthropoda & Palaemonetes pugio & Adult & 45 & Survival, weight, length & 0.098 (chronic NOEC) & Volz et al. (2003) \\
\hline Arthropoda & Amphiascus tenuiremis & Adult & 4 & Mortality & $6.8\left(\mathrm{LC}_{50}\right)$ & Chandler et al. (2004) \\
\hline Arthropoda & Amphiascus tenuiremis & Nauplii & $12-17$ & $\begin{array}{l}\text { Mature to adult; egg } \\
\text { production }\end{array}$ & 0.22 (LOEC) & Chandler et al. (2004) \\
\hline Arthropoda & Amphiascus tenuiremis & $\begin{array}{l}\text { Adult } \\
\text { (female/male) }\end{array}$ & 4 & Mortality & $6.07 / 3.86\left(\mathrm{LC}_{50}\right)$ & Bejarano et al. (2005) \\
\hline Arthropoda & Americamysis bahia & $<24 \mathrm{~h}$ & 28 & Mortality & 0.0034 (chr. est. NOEC) & USEPA (2015) \\
\hline Arthropoda & Farfantepenaeus aztecus & Juvenile & 29 & Mortality & $1.3\left(96-h L_{50}\right)$ & Al-Badran et al. (2018) \\
\hline Rotifera & Brachionus plicatilis & Adult & 1 & Population growth & 1000 (NOEC) & Lee et al. (2018) \\
\hline \multicolumn{7}{|l|}{ Imidacloprid } \\
\hline Cnidaria & Acropora tenuis & Larvae & 2 & Metamorphosis & 263 (NEC) & Present study \\
\hline Arthropoda & Palaemonetes pugio & Larvae & 4 & Mortality & $308.8\left(\mathrm{LC}_{50}\right)$ & Key et al. (2007) \\
\hline Arthropoda & Palaemonetes pugio & Adult & 4 & Mortality & $563.5\left(\mathrm{LC}_{50}\right)$ & Key et al. (2007) \\
\hline Arthropoda & Callinectes sapidus & Megalopae & 1 & Mortality & $10.04\left(L_{50}\right)$ & Osterberg et al. (2012) \\
\hline Arthropoda & Callinectes sapidus & Juvenile & 1 & Mortality & $1112\left(\mathrm{LC}_{50}\right)$ & Osterberg et al. (2012) \\
\hline Arthropoda & Americamysis bahia & Juvenile & 4 & Mortality & $37.7\left(\mathrm{LC}_{50}\right)$ & USEPA (2015) \\
\hline Arthropoda & Americamysis bahia & Not stated & 4 & Mortality & $38\left(\mathrm{EC}_{50}\right)$ & USEPA (2015) \\
\hline Arthropoda & Americamysis bahia & Not stated & 4 & Mortality & $159\left(\mathrm{EC}_{50}\right)$ & USEPA (2015) \\
\hline Arthropoda & Mysidopsis bahia & Adult & 4 & Mortality & 13.3 (NOEC) & Ward (1990) \\
\hline
\end{tabular}




\begin{tabular}{|c|c|c|c|c|c|c|}
\hline $\begin{array}{l}\text { Arthropoda } \\
\text { Chordata }\end{array}$ & $\begin{array}{l}\text { Artemia sp. } \\
\text { Menidia beryllina }\end{array}$ & $\begin{array}{l}\text { Adult } \\
\text { Larval }\end{array}$ & $\begin{array}{l}2 \\
7\end{array}$ & $\begin{array}{l}\text { Mortality } \\
\text { Growth inhibition }\end{array}$ & $\begin{array}{l}361000\left(L_{50}\right) \\
34000(\text { LOEC) }\end{array}$ & $\begin{array}{l}\text { Song et al. (1997) } \\
\text { Environment Canada } \\
(2005)\end{array}$ \\
\hline \multicolumn{7}{|l|}{ Chlorothalonil } \\
\hline Cnidaria & Acropora tenuis & Larvae & 2 & Metamorphosis & 2.42 (NEC) & Present study \\
\hline Chlorophyta & Dunaliella tertiolecta & $\begin{array}{l}\text { Log growth } \\
\text { phase }\end{array}$ & 4 & Population growth & 33 (NOEC) & $\begin{array}{l}\text { DeLorenzo \& Serrano } \\
\text { (2003) }\end{array}$ \\
\hline Arthropoda & Amphiascus tenuiremis & $\begin{array}{l}\text { Adult } \\
\text { (female/male) }\end{array}$ & 4 & Mortality & $53.1 / 26.7\left(\mathrm{LC}_{50}\right)$ & Bejarano et al. (2005) \\
\hline Chordata & Ciona intestinalis & Embryo & 2 & Embryonic development & $12\left(\mathrm{EC}_{10}\right)$ & Bellas (2006) \\
\hline Mollusca & Mytilus edulis & Embryo & 2 & Embryonic development & $4.5\left(\mathrm{EC}_{10}\right)$ & Bellas (2006) \\
\hline Echinodermata & Paracentrotus lividus & Embryo & 2 & Embryonic development & $4.3\left(E_{10}\right)$ & Bellas (2006) \\
\hline Bacillariophyta & Skeletonema costatum & Not stated & 14 & Population growth & 5.9 (chronic NOEL) & USEPA (2015) \\
\hline Arthropoda & Americamysis bahia & Early life stage & 28 & Mortality & 0.83 (chronic NOEL) & USEPA (2015) \\
\hline \multicolumn{7}{|l|}{ Propiconazole } \\
\hline Cnidaria & Acropora tenuis & Larvae & 2 & Metamorphosis & 269 (NEC) & Present study \\
\hline Mollusca & Crassostrea virginica & Spat & 4 & Cell density & 170 & USEPA (2015) \\
\hline Arthropoda & Americamysis bahia & Not stated & 4 & Mortality & 51 & USEPA (2015) \\
\hline Chlorophyta & Dunaliella tertiolecta & $\begin{array}{l}\text { Log growth } \\
\text { phase }\end{array}$ & 4 & Population growth & 375 (NOEC) & $\begin{array}{l}\text { Baird \& DeLorenzo } \\
\text { (2010) }\end{array}$ \\
\hline Bacillariophyta & Skeletonema costatum & Not stated & 11 & Population growth & 5.5 (chr. est. NOEC) & USEPA (2015) \\
\hline Chordata & Cyprinodon variegatus & Early life stage & 100 & Mortality & 150 (NOEL) & USEPA (2015) \\
\hline
\end{tabular}




\section{Table 4 (on next page)}

WQGV and PGV

Australian water quality guideline values (from ANZG 2018 ) for diazinon and Department of Environment and Science (DES) proposed guideline values for fipronil, imidacloprid, chlorothalonil and propiconazole for $99 \%, 95 \%, 90 \%$ and $80 \%$ species protection in marine ecosystems (from King et al. 2017a, King et al. 2017b). WQGV - water quality guideline value; PGV - proposed guideline value; NEC - no effect concentration. All concentrations are in $\mu \mathrm{g} \mathrm{L}^{-1}$ (95\% confidence intervals). 


\begin{tabular}{|c|c|c|c|c|c|c|c|c|c|c|}
\hline \multirow[t]{2}{*}{ Pesticide } & \multicolumn{4}{|l|}{ WQGV } & \multicolumn{4}{|l|}{ PGV } & \multirow{2}{*}{$\begin{array}{l}\text { Guideline } \\
\text { reliability }\end{array}$} & \multirow{2}{*}{$\begin{array}{l}\text { NEC - } \\
\text { this study }\end{array}$} \\
\hline & PC99 & PC95 & PC90 & PC80 & PC99 & PC95 & PC90 & PC80 & & \\
\hline Diazinon* & 0.00003 & 0.01 & 0.2 & 2.0 & & & & & Unknown & 38.0 \\
\hline Fipronil** & & & & & 0.0034 & 0.0089 & 0.016 & 0.033 & Moderate & 12.3 \\
\hline Imidacloprid*** & & & & & 0.057 & 0.13 & 0.23 & 0.46 & Moderate & 263 \\
\hline Chlorothalonil & & & & & 0.34 & 1.0 & 1.7 & 2.9 & Moderate & 2.42 \\
\hline Propiconazole & & & & & 2.1 & 8.2 & 15 & 30 & Low & 269 \\
\hline
\end{tabular}

*Diazinon WQGVs derived from freshwater data only as insufficient marine toxicity data to derive reliable guideline value

**Fipronil PGVs includes toxicity data from six freshwater species. No toxicity data were found for fipronil to Australian and/or New Zealand marine species

***Imidacloprid PGVs were calculated from toxicity data from only arthropods due to bimodality in SSD. Data includes toxicity data from two freshwater species 